\title{
Interaction of Agouti protein with the melanocortin 1 receptor in vitro and in vivo
}

\author{
Michad M. OlImann, ${ }^{1}$ M. Lynn Lamoreux, ${ }^{2}$ Brent D. Wilson, ${ }^{1}$ and Gregory S. Barsh ${ }^{1,3}$ \\ ${ }^{1}$ Departments of Pediatrics and Genetics, and the Howard Hughes Medical Institute, Stanford University School of \\ M edicine, Stanford, California 94305-5428; '2 Department of Veterinary Pathobiology, Texas A\&M University, \\ College Station, Texas 77843 USA
}

\begin{abstract}
Agouti protein and Agouti-related protein (Agp) are paracrine-signaling molecules that normally regulate pigmentation and body weight, respectively. These proteins antagonize the effects of $\alpha$-melanocytestimulating hormone ( $\alpha$-MSH) and other melanocortins, and several alternatives have been proposed to explain their biochemical mechanisms of action. We have used a sensitive bioassay based on Xenopus melanophores to characterize pharmacologic properties of recombinant Agouti protein, and have directly measured its cell-surface binding to mammalian cells by use of an epitope-tagged form (HA-Agouti) that retains biologic activity. In melanophores, Agouti protein has no effect in the absence of $\alpha$-MSH, but its action cannot be explained solely by inhibition of $\alpha$-MSH binding In 293T cells, expression of the Mclr confers a specific, high-affinity binding site for HA-Agouti. Binding is inhibited by $\alpha-M S H$, or by Agp, which indicates that $\alpha-M S H$ and Agouti protein bind in a mutually exclusive way to the Mclr, and that the similarity between Agouti protein and Agrp includes their binding sites. The effects of Agouti and the Mclr in vivo have been examined in a sensitized background provided by the chinchilla $\left(\mathrm{Trr}^{\mathrm{c}-\mathrm{ch}}\right)$ mutation, which uncovers a phenotypic difference between overexpression of Agouti in lethal yellow ( $\mathrm{A} / \mathrm{a}$ ) mice and loss of Mclr function in recessive yellow $\left(\mathrm{Mclr}^{\mathrm{e}} / \mathrm{Mclr}^{\mathrm{e}}\right)$ mice. Double and triple mutant studies indicate that a functional Mclr is required for the pigmentary effects of Agouti, and suggest that Agouti protein can act as an agonist of the Mclr in a way that differs from $\alpha-M S H$ stimulation. These results resolve questions regarding the biochemical mechanism of Agouti protein action, and provide evidence of a novel signaling mechanism whereby $\alpha$-MSH and Agouti protein or Agp function as independent ligands that inhibit each other's binding and transduce opposite signals through a single receptor.
\end{abstract}

[Key Words: Agouti; melanocortin receptor; pigmentation; obesity; mouse coat color]

Received September 26, 1997; revised version accepted N ovember 14, 1997.

A large collection of mouse coat color genes discovered over the past fifty years has proven to be a valuable resource for identifying and studying general aspects of cell biology. Two such genes, Agouti and Extension, encode a paracrine-signaling molecule and a $G$ protein-coupled receptor (the $\mathrm{Mclr}$ or melanocortin 1 receptor), respectively, and are opposing regulators of pigment production in hair follicle melanocytes (Bultman et al. 1992; Miller et al. 1993; Robbins et al. 1993). Mammalian melanocytes can produce either eumelanin (black/brown pigment) or pheomelanin (yellow/red pigment) (for review, see Prota 1992). Local production of Agouti protein by specialized cells in the dermis causes follicular melanocytes to produce pheomelanin, whereas activation of the Mclr in melanocytes leads to the production of eumelanin (Geschwind 1966; Chhajlani and Wikberg 1992;

${ }^{3}$ Corresponding author.

E-MAIL gbarsh@cmgm.stanford.edu; FAX (650) 723-1399.
Mountjoy et al. 1992; Millar et al. 1995). The Mclr can be activated by melanocortin peptides such as $\alpha$-melanocyte stimulating hormone $(\alpha-\mathrm{MSH})$ and adrenocorticotrophic hormone (ACTH) (for review, see Eberle 1988; Cone et al . 1996), but the extent to which these peptides normally control mammalian pigmentation is not clear.

The interaction between Agouti protein and the Mclr is likely to be representative of similar interactions that occur between additional melanocortin receptor subtypes and agouti-related molecules in the regulation of other biological processes (Adan et al. 1996; Li et al. 1996; Fan et al. 1997; Huang et al. 1997; Ollmann et al. 1997; Shutter et al. 1997). This possibility was first suggested by the phenotype of mice carrying the dominant Agouti allele lethal yellow $\left(A^{y}\right)$ in which transcripts encoding normal Agouti protein are ubiquitously expressed (Miller et al. 1993; Michaud et al. 1994). In addition to a yellow coat, mice that carry $A^{y}$ display obesity, insulin resistance, premature infertility, increased body length, 
and increased tumor susceptibility (for review, see Silvers 1979a). Many of these phenotypes appear to be caused by inhibition of the CN S-specific mel anocortin 4 receptor (M c4r) (Gantz et al. 1993), because mice that carry a targeted mutation of the $M c 4 r$ recapitulate the metabolic and growth abnormalities observed in $A^{y} /-$ mice (Huszar et al. 1997), and recombinant Agouti protein can antagonize the effects of Mc4r stimulation in vitro (Lu et al. 1994; Yang et al. 1997). Ectopic expression of Agouti in mice that carry $A^{y}$ or similar alleles (for review, see Siracusa 1994) probably mimics the function of a recently discovered homologous protein, Agouti-related protein (Agrp), which is normally expressed in the hypothalamus, causes obesity when ubiquitously expressed, and can antagonize the effects of M c4r stimulation in vitro (Ollmann et al. 1997; Shutter et al. 1997).

The exact mechanism by which Agouti protein and Agrp inhi bit mel anocortin-receptor signaling is not completely clear. In vitro, recombinant Agouti protein will inhibit binding of radiolabeled melanocortins to cells that express melanocortin receptors (Lu et al. 1994; Y ang et al. 1997), suggesting that Agouti protein binds melanocortin receptors and acts as a competitive antagonist of ligand binding, even though Agouti protein and melanocortin peptides exhibit no sequence similarity. This model is supported by studies of Agouti protein in B16 melanoma cells, in which doseresponse curves of $(\alpha-$ $\mathrm{MSH}$ )-stimulated CAMP accumulation in the presence of Agouti protein were consistent with simple competitive antagonism (Blanchard et al. 1995; Willard et al. 1995). Other studies, however, suggest al ternative mechanisms of Agouti protein action. Agouti protein will inhibit the effects of forskolin or cholera toxin in cultured pigment cells (Siegrist et al. 1997; Suzuki et al. 1997), and several groups have observed that Agouti protein has physiol ogic effects in the absence of added melanocortin peptides (Hunt and Thody 1995; Si egrist et al . 1996; Sakai et al. 1997). In contrast to laboratory mice, where a constitutively active Mclr mutation is epistatic to a dominant Agouti allele (for review, see Silvers 1979a), Arctic foxes that carry a constitutively active Mclr allele still display a coat color response to A gouti (Vage et al. 1997), which suggests the existence of an as yet unidentified Agouti receptor whose downstream effectors intersect with those of the Mclr. On the basis of the similarity of cysteine spacing between Agouti protein and invertebrate toxins that inactivate calcium channels (Olivera et al. 1991; Quistad and Skinner 1994), Zemel and colleagues have suggested that Agouti protein can regulate intracelI ular cal cium levels (Zemel et al. 1995; Jones et al. 1996; Kim et al. 1996; Mynatt et al. 1997), possibly by binding to a specific Agouti receptor (M anne et al. 1995). Additional reports hypothesize that Agouti protein promotes melanocortin-receptor internalization, or that it functions as an inverse agonist of melanocortin receptors (Si egrist et al. 1996, 1997).

Direct measurements of Agouti protein binding could help to resolve some of the uncertainties regarding its mechanism of action. To this end, we have made use of a rapid and sensitive bioassay based on amphibian pig- ment cells, Xenopus melanophores (Potenza and Lerner 1992), to purify and characterize mouse Agouti protein and an epitope-tagged form of A gouti protein that retains biologic activity. We find that expression of the Mclr confers a specific cell-surface binding site for A gouti protein in vitro. Binding is inhibited by $\alpha-\mathrm{MSH}$, or by Agrp, which shows that $\alpha-\mathrm{MSH}$ and Agouti protein bind in a mutually exclusive way to the Mclr, and that Agouti protein and Agrp bind to a common site. To investigate, in vivo, whether all the effects of Agouti protein can be explained by its ability to inhibit $\alpha-\mathrm{MSH}$ binding, we have carried out genetic crosses on a background sensitized to the effects of $A^{y}$. We find that the coat color phenotype of mice that ubiquitously express Agouti differs from those that lack a functional $\mathrm{Mclr}$, and that the phenotype of double-mutants is identical to that caused by Mclr deficiency. Thus, the effects of Agouti require a functional $\mathrm{Mclr}$, but the receptor appears to respond independently to each factor in vivo. These findings have general implications for understanding melanocortin-receptor signaling.

\section{Results}

Agouti protein specifically inhibits $\alpha$-MSH-induced pigment dispersion in Xenopus melanophores

Measurements of Agouti protein activity described by us and others have been based on inhibition of $\alpha-\mathrm{MSH}$ action in cultured melanocytes or in heterologous cells transfected with a mammalian melanocortin receptor (Lu et al. 1994; Blanchard et al. 1995; Sakai et al. 1997; Y ang et al. 1997). As described below, we found that a bi oassay based on cultured Xenopus melanophores is a more rapid and accurate method for detecting Agouti protein activity. In the permanent melanophore cell line derived by Lerner and colleagues (Potenza and Lerner 1992), agents that al ter intracellular cAM P level s cause a rapid change in pigment granule dispersion that is visible to the eye and can be quantitated in a 96-well format. The melanophores are very sensitive to $\alpha-\mathrm{MSH}$ (EC50 of $0.9 \mathrm{~nm}$ ), and have been used previously to characterize small molecule melanocortin agonists and antagonists (Jayawickreme et al. 1994).

By use of inhibition of $\alpha-\mathrm{MSH}$-induced pigment dispersion in melanophores as an assay, we purified recombinant Agouti protein from conditioned media of insect cells infected with a baculovirus that contained the mouse Agouti cDNA. Two 18-kD isoforms were re solved at $>99 \%$ purity after cation and anion exchange chromatography (Fig. 1B); the two isoforms differed in their charge but had identical specific activity (not shown). Amino-terminal sequencing revealed both forms to be mature Agouti protein cleaved at the predicted signal-sequence cleavage site. M ass spectrometry indicated the difference in charge and electrophoretic mobility of the two isoforms is caused by differential glycosylation (Fig. 1B), most likely at the amino-linked glycosylation site described by Wilkison and colleagues (Willard et al. 1995). 
Figure 1. Production and characterization of recombinant Agouti protein with Xenopus melanophores. (A) Photograph of confluent melanophores in 96-well plate $45 \mathrm{~min}$ after treatment with the indicated concentrations of Agouti protein and $\alpha-\mathrm{MSH}$. Agouti protein has no effect by itself but inhibits pigment granule dispersion induced by $\alpha$-MSH. (B) Recombinant Agouti protein analyzed by silver stained $4 \%-20 \%$ SDSPAGE. Each lane contains $1 \mu \mathrm{g}$ of protein from serial steps in the purification as described in M aterials and M ethods. CM, conditioned media produced by baculovirus-infected cells; CE, product of cation exchange; $A E 1$ and $A E 2$, products of anion exchange that differ in their extent of glycosylation but not in their primary sequence as determined by mass spectrometry and amino-terminal sequencing. (C) Effect of forskolin on melanophore pigment dispersion in the presence $(\bigcirc)$ and absence (control, $\mathbf{\square})$ of $100 \mathrm{~nm}$ Agouti protein. (D) Dose-response analysis of Agouti protein antagonism measured by pigment dispersion in melanophores 220 min after simultaneous addition of Agouti protein and $\alpha-\mathrm{MSH}$. The experiment was carried out as described in Materials and Methods, except that different concentrations of Agouti protein and $\alpha-\mathrm{MSH}$ were mixed in a 96-well plate before addition to melanophores. The $\alpha-\mathrm{MSH}$ dose-response curves at different Agouti concentrations, $0.6 \mathrm{~nm}$ to $150 \mathrm{~nm}$, exhibit slopes that are significantly different from each other $(F=21.8$, $\mathrm{P}<0.001$ ) as determined by a goodness-of-fit test that compares curve-fitting individual sl opes for each concentration of A gouti protein with a single slope for all eight $\alpha-\mathrm{MSH}$ dose-response curves. Similar results were obtained 35 min after simultaneous addition of Agouti protein and $\alpha-\mathrm{MSH}(\mathrm{F}=7.9, \mathrm{P}<0.001)$.
Purified Agouti protein had no effect on mel anophores by itself (Fig. 1A; data not shown), but inhibited pigment dispersion induced by $\alpha-$ M SH (Fig. 1A,D) or related peptides including des-Acetyl- $\alpha$-M SH or [N Ie4, D-Phe7]- $\alpha$ MSH (NDP-MSH; not shown). Differences in Agouti protein concentration of $<1 \mathrm{nM}$ can be detected in the mel anophore assay; the lower limit of detection is $\sim 0.5$ nм (Fig. $1 A, D)$. A gouti protein did not inhibit pigment dispersion caused by agents which, like $\alpha-\mathrm{MSH}$, increase adenylate-cyclase activity. For example, forskolin, a direct activator of adenylate cyclase, produces a dose-dependent dispersion of pigment granules in Xenopus melanophores that is unaffected by $100 \mathrm{~nm}$ Agouti protein (Fig. 1C). Similar results were observed with the agonists norepinephrine and isoproterenol (not shown), which stimulate the endogenous adrenergic receptor expressed on melanophores.

\section{Agouti protein does not bind or inactivate $\alpha$-MSH}

Interaction of Agouti protein with cell-surface binding sites has been inferred by its ability to inhibit melanocortin binding or activity. These findings, however, could also be explained by ligand sequestration or inac-
A

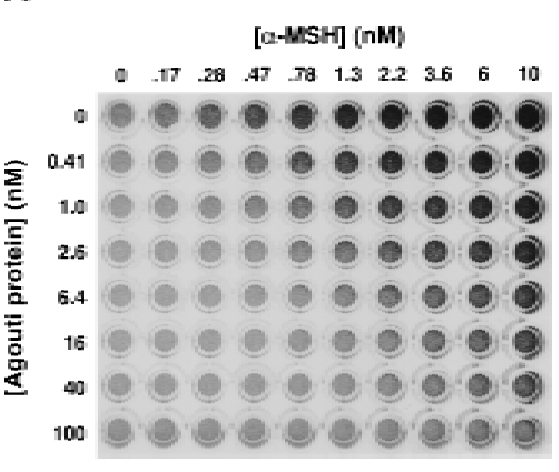

B

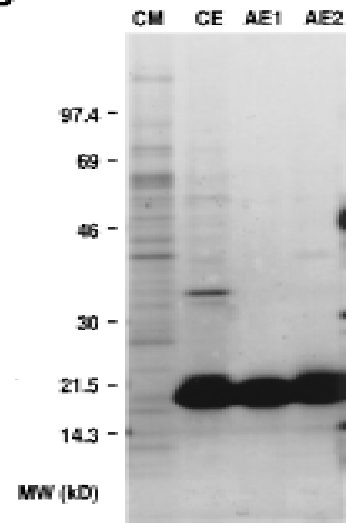

C

D

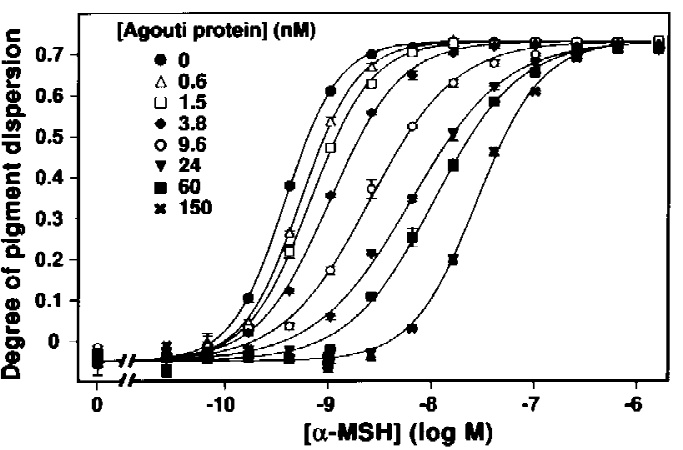




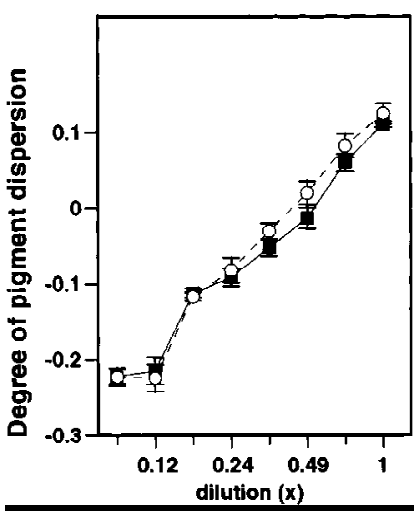

Figure 2. Lack of interaction between Agouti protein and $\alpha$ MSH assayed by filtration binding. $\alpha-\mathrm{MSH}$ (4 nM) was mixed with either $130 \mathrm{~nm}$ A gouti protein $(\bigcirc)$ or $130 \mathrm{~nm}$ BSA (ם) in $2 \mathrm{ml}$ of $70 \%$ L-15 media, then subjected to $2 \mathrm{hr}$ of filter centrifugation with a 3-kD filter (Centriprep 3, Amicon, Beverly, MA). Serial dilutions of the two filtrates were assayed for pigment dispersion activity, and no differences were apparent between the Agouti protein and the BSA samples. Testing the retentates for pigment dispersion activity (not shown) confirmed that the Agouti protein remained active after the centrifugation.

nophores only become apparent after pigment dispersion is stimulated with $\alpha-\mathrm{MSH}$, Agouti protein seems likely to act via the endogenous mel anocortin receptor on meIanophores. To investigate further if these effects could be explained entirely by inhibition of $\alpha-\mathrm{MSH}$ binding, we analyzed dose-response curves of $\alpha-\mathrm{MSH}$-induced pigment dispersion in the presence of various concentrations of A gouti protein. For an antagonist that acts sol ely by preventing agonist binding, increasing concentrations of antagonist cause a proportionate rightward shift of the agonist dose-response curve but do not affect its minimum, maximum, or slope at equilibrium, and the antagonist is said to be competitive (Kenakin 1982). In most mammalian cell systems, depression of maximal signaling or lack thereof are the primary criteria used to assess competitive antagonism; the precision of the meIanophore assay, however, offers the additional opportunity to evaluate whether or not the shape of the dosereponse curve is independent of antagonist.

We found that concentrations of Agouti protein up to $150 \mathrm{~nm}$ had no effect on maximal levels of $\alpha-\mathrm{MSH}$-induced pigment dispersion, but significantly altered the slope of the doseresponse curve (Fig. 1D; F =21.5; $P<0.001)$. The results depicted in Figure 1D represent pigment dispersion 220 min after simultaneous addition of Agouti protein and $\alpha-\mathrm{M} \mathrm{SH}$. Experiments in which pigment dispersion was measured for shorter periods of time (not shown) yiel ded similar results; at no time did the different $\alpha-\mathrm{M} \mathrm{SH}$ dose-response curves exhibit identical slopes, as expected for a competitive antagonist.

The kinetics of A gouti protein action in melanophores al so suggest it has effects beyond si mply inhi biting binding of $\alpha-\mathrm{MSH}$. We preincubated melanophores with 15 nм A gouti protein for various times from 25 to $360 \mathrm{~min}$, added $\alpha-\mathrm{MSH}$, and then measured pigment dispersion after an additional 30 min (Fig. 3). Compared with control buffer, $15 \mathrm{~nm}$ Agouti caused a rightward displacement of the $\alpha$-MSH dose-response curve by $\sim 1.2$ log units after a 25-min preincubation; after a 315-min incubation, the $\alpha-\mathrm{MSH}$ dose-response curve was displaced further to the right by an additional $0.8 \log$ units (Fig. 3A). Thus, the ability of Agouti protein to inhibit $\alpha-\mathrm{MSH}$-induced pigment dispersion increases gradual ly over nearly $6 \mathrm{hr}$, even though Agouti protein by itself has no effect on pigment dispersion (Fig. 3; data not shown).

A potential explanation for the time-dependent potentiation in inhibition of $\alpha-\mathrm{MSH}$-induced pigment dispersion by Agouti protein is a slow on-rate, such that equilibrium is not reached for at least $6 \mathrm{hr}$. Alternatively, Agouti protein might reach equilibrium between bound and sol uble pools quickly, but cause a gradual desensitization in the ability of the cells to respond to $\alpha-\mathrm{MSH}$ by inducing, for example, Mclr internalization and/or a post-translational modification of the Mclr that alters coupling to downstream effectors. To help distinguish among these al ternatives, we carried out the preincubation experiment at $8^{\circ} \mathrm{C}$, which should reduce or eliminate desensitization, but would have no effect on, or possibly exaggerate, the time to reach equilibrium between bound and soluble pools. During a $25 \mathrm{~min}$ preincubation at $8^{\circ} \mathrm{C}, 20 \mathrm{~nm}$ A gouti protein caused a rightward displacement of the $\alpha-\mathrm{MSH}$ dose-response curve by $\sim 1.2 \mathrm{log}$ units, and continued incubation up to 355 min produced no further effect (Fig. 3B). The effects of time and temperature on Agouti protein action are most easily compared by measurements of the Dose Ratio, defined as the amount of $\alpha-\mathrm{MSH}$ required to produce half-maximal pigment dispersion in the presence of Agouti protein, divided by the amount of $\alpha-\mathrm{MSH}$ required to produce halfmaximal pigment dispersion in the absence of Agouti protein. The dose ratio increases with continued preincubation at $22^{\circ} \mathrm{C}$ but not at $8^{\circ} \mathrm{C}$ (Fig. $3 \mathrm{C}$ ), which is not easily explained by failure to reach equilibrium between bound and soluble pools. Instead, the effect of Agouti protein on the slope of $\alpha-\mathrm{MSH}$ dose-response curves, along with the increase in Agouti protein activity following preincubation, suggests that Agouti protein can cause receptor desensitization by a time and temperature-dependent mechanism. Taken together, these results suggest that Agouti protein affects $\alpha-\mathrm{MSH}$ signaling in two ways: direct inhibition of $\alpha-\mathrm{MSH}$ binding and receptor desensitization.

Specific binding of epitope-tagged Agouti protein to cells that express the $\mathrm{Mclr}$

To help resolve some of the uncertainties regarding the mechani sm of Agouti protein action, we developed a system for di rectly measuring its cell-surface binding. Initial attempts at radioiodination rendered Agouti protein biologically inactive. Therefore, we employed an alternative approach based on immunofluorescence. We constructed a modified form of Agouti protein that contained a hemagglutinin epitope 6 residues downstream 


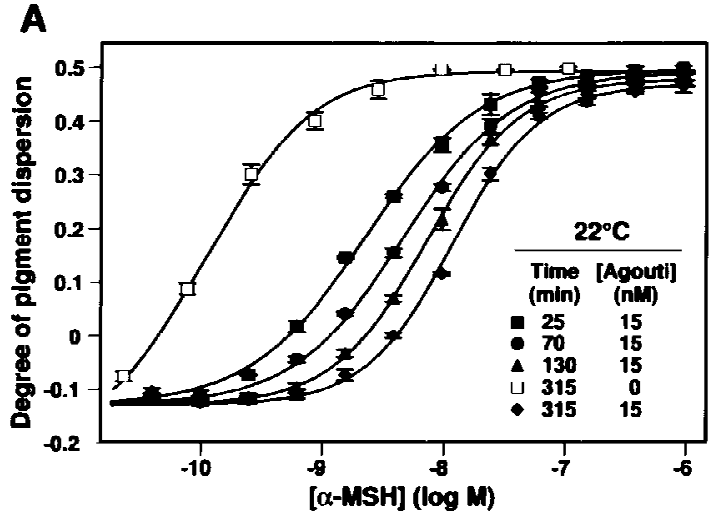

B

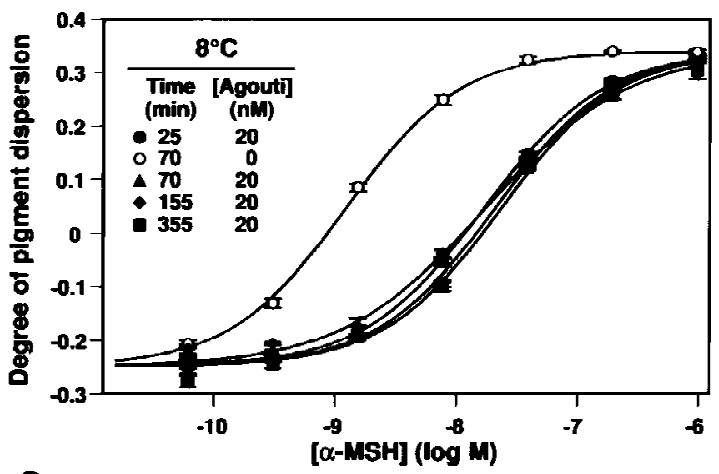

C

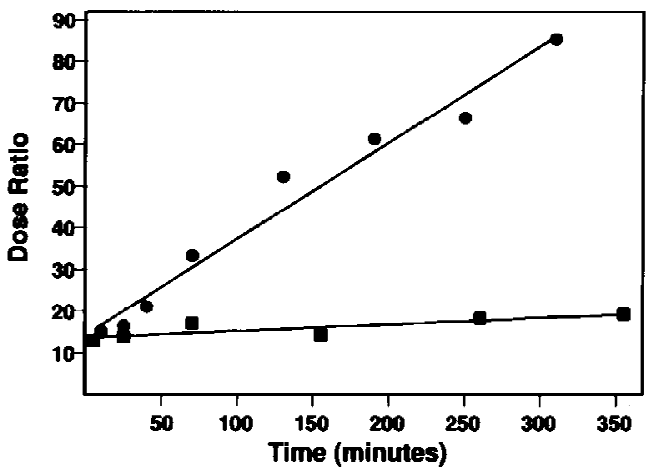

Figure 3. Time and temperature dependence of A gouti protein action. (A) Melanophores were preincubated with 15 or $0 \mathrm{~nm}$ (buffer only) Agouti protein for the indicated length of time at $22^{\circ} \mathrm{C}$, various concentrations of $\alpha-\mathrm{MSH}$ were added for an additional $30 \mathrm{~min}$, and the degree of pigment dispersion was determined as described in $M$ aterials and $M$ ethods. Preincubation in buffer does not alter the response to $\alpha-\mathrm{MSH}$, therefore, only one time point (315 $\mathrm{min})$ is shown. Only four of the eight preincubation times in Agouti protein (25, 70, 130, and $315 \mathrm{~min}$ ) are displayed. (B) Preincubation at $8^{\circ} \mathrm{C}$. Same as in A except melanophores were kept at $8^{\circ} \mathrm{C}$ during preincubation with $20 \mathrm{~nm}$ Agouti protein, then incubated at $22^{\circ} \mathrm{C}$ following addition of $\alpha-\mathrm{M} \mathrm{SH}$. Qual itatively similar results (not shown) are obtained if the entire experiment is carried out at $8^{\circ} \mathrm{C}$. (C) Kinetics of Agouti protein activity at $8{ }^{\circ} \mathrm{C}(\boldsymbol{\square})$ and $22^{\circ} \mathrm{C}(\bullet)$ as measured by the dose ratio. For each time point, the dose ratio is calculated as $([\alpha-\mathrm{MSH}]$ that yields half-maximal pigment dispersion in the presence of Agouti protein/[ $\alpha-\mathrm{MSH}]$ that yields half-maximal pigment dispersion in the presence of $20 \mathrm{~nm}$ Agouti buffer). The abscissa denotes time of preincubation with Agouti protein. of the signal-sequence cleavage site. Recombinant epitope-containing protein (HA-Agouti) was produced in baculovirus, purified by cation exchange, and found to exhibit a specific activity in the melanophore assay equal to that of the native protein (data not shown).

To measure cell-surface binding, we incubated a $25 \mathrm{~nm}$ solution of HA-A gouti at $4^{\circ} \mathrm{C}$ for $3 \mathrm{hr}$ with $293 \mathrm{~T}$ cells transiently transfected with the Mclr, fixed the cells with $2 \%$ formal dehyde, and detected bound HA-Agouti by immunofluorescence. To help ensure that adequate levels of Mclr were produced after transfection, most experiments were carried out with a form of the $\mathrm{Mclr}$ modified by addition of a Flag epitope at its amino terminus (Flag-MClr). Staining replicate samples either with an Anti-HA antibody or an Anti-Flag antibody then indicated binding of HA-Agouti or expression of the Flag-M clr, respectively. In addition, to hel p identify the $10 \%$ to $20 \%$ of cells that were transfected and express receptor at high levels, a green fluorescence protein (GFP) expression plasmid was cotransfected with each receptor plasmid in a 1:10 molar ratio.

We found that transfection of either the Mclr or the Flag-M c1r (Fig. 4C) conferred on 293T cells the ability to bind HA-Agouti; whereas untransfected cells or those transfected with a control Flag- $\beta 2$ adrenergic receptor (Flag-B2AR, Fig. 4G) did not bind HA-Agouti (Table 1). $\mathrm{HA}-\mathrm{A}$ gouti binding is specific, as it is not detected in the presence of an 8-fold (Table 1) or a 20-fold (Fig. 4E) molar excess of $>99 \%$ pure native Agouti protein. Addition of HA-tagged or native Agouti protein did not visibly alter levels of Flag-M clr present at the cell surface (Fig. 4D,F). $\mathrm{N}$ early all the cells that bound HA-Agouti also expressed GFP (Fig. 4C; Table 1). Fixation in $2 \%$ formaldehyde was required for detection of binding, which suggests that binding of HA-Agouti is reversible (Table 1 ). Dissociation of HA-A gouti must occur sl owly, however, because our procedure includes a 50 min wash in phosphate-buffered sal ine prior to fixation. We were unable to detect binding of HA-Agouti to melanophores (Table 1), possibly because of differences in receptor number and/ or affinity compared with 293T cells transiently transfected with the Mclr.

The effect of $\alpha-\mathrm{MSH}$ and Agrp on Agouti protein binding

The findings described above strongly support a direct interaction between Agouti protein and the $\mathrm{Mcl}$, but do not exclude the possibility that Agouti protein binds to an unknown factor recruited to the cell surface by expression of the Mclr. To address this possibility, we asked whether the mel anocortin receptor ligand $\alpha-\mathrm{M} \mathrm{SH}$ could inhibit the binding of HA-Agouti. Two hundred and fifty nanomolar $\alpha-M S H$ had no effect on cell-surface expression of the Flag-Mclr (Fig. 5B), but completely bl ocked the binding of $25 \mathrm{~nm} \mathrm{HA-A} \mathrm{gouti} \mathrm{(Fig.} \mathrm{5A).} \mathrm{NDP-}$ MSH also inhibited binding of HA-Agouti (Table 1). In contrast, addition of $2 \mu \mathrm{m}$ bombesin, a small peptide lacking specificity for melanocortin receptors, had no ef- 


\section{Additions and (receptor) : \\ None
(FLAG-Mc1r) \\ 25 nM HA-Agouti (FLAG-Mc1r)}

\section{5 nM HA-Agouti $+500 \mathrm{nM}$ Agouti (FLAG-Mc1r)}

\section{5 nM HA-Agouti (FLAG-beta2r)}
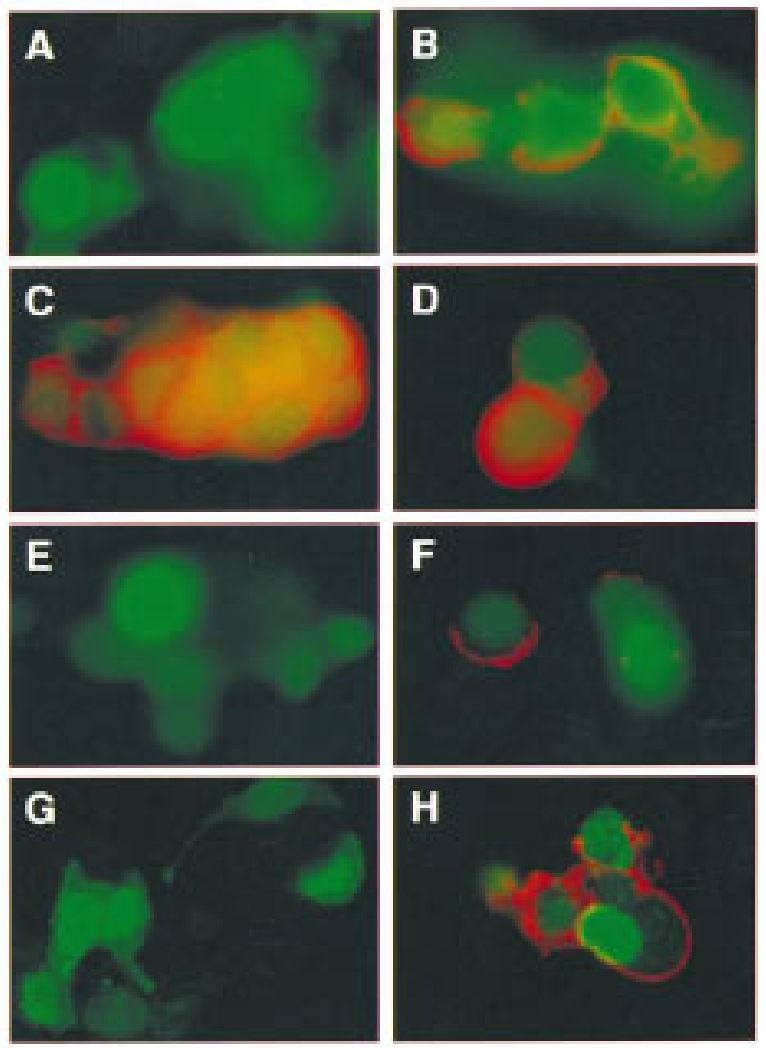

$1^{\circ}$ AB: Anti-HA

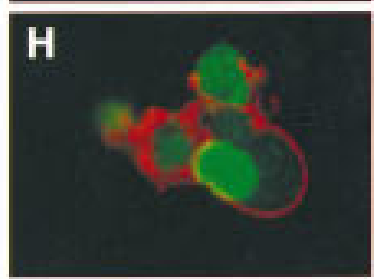

$1^{\circ}$ AB: Anti-FLAG
Figure 4. Binding of epitope-tagged Agouti protein to Mclr-expressing cells. 293T cells were cotransfected with expression plasmids for GFP and the Flag-Mclr (A-F) or the FlagB2AR $(G, H)$ as described in Materials and $M$ ethods. Transfected cells were incubated in 0 nm Agouti (A,B), 25 nм HA-Agouti $(C, D, G, H)$, or $25 \mathrm{~nm}$ HA-Agouti plus $500 \mathrm{~nm}$ (untagged) Agouti protein $(E, F)$. Binding of HA-Agouti was detected by immunofluorescence with an anti$\mathrm{HA}$ antibody $(A, C, E, G)$; expression of the Flag$\mathrm{Mclr}$ or the Flag-B2AR was detected by immunofluorescence with an anti-Flag antibody $(B, D, F, H)$ as described in Materials and Methods. Green staining represents GFP expression and red staining represents bound $\mathrm{HA}-\mathrm{Agouti}$ $(A, C, E, G)$ or receptor expression $(B, D, F, H)$. All panels represent experiments summarized in Table 1. fect on binding of HA-Agouti (not shown). Because all of the binding studies were carried out at $4^{\circ} \mathrm{C}$, it is unlikely that the ability of $\alpha-\mathrm{MSH}$ to block HA-Agouti binding is caused by internalization or degradation of an unknown protein specific for Agouti binding. Instead, we conclude that Agouti and $\alpha$-MSH bind in a mutually exclusive way to the Mclr.

We al so asked if Agrp, a newly described neuropeptide that may regulate body weight in response to leptin signaling (Ollmann et al. 1997; Shutter et al. 1997), could affect binding of HA-Agouti. Agouti and Agrp exhibit $44 \%$ amino acid identity in the carboxy-terminal cysteine-rich region required for antagonism by Agouti protein (Willard et al. 1995), and we have shown recently that recombinant Agrp can act as a potent $\mathrm{Mc3r}$ and Mc4r antagonist in vitro, which suggests that Agouti protein and Agrp act via a similar biochemical mechanism.

Recombinant Agrp produced in the baculovirus system can be purified in two fractions which exhibit biologic activity (Ollmann et al. 1997). One fraction contains a mixture of mature full-length protein and proteoIytically cleaved forms shortened at their amino termini by $26-30$ residues (Fig. $5 \mathrm{H}$, forms $\mathrm{A}+\mathrm{B}$ ). A second fraction contains forms that are further shortened and comprised mainly of the carboxy-terminal cysteine-rich region (Fig. $5 \mathrm{H}$, form C).

We found that high concentrations of either A grp frac- tion would inhibit binding of HA-Agouti to cells transfected with the Flag-Mclr (Fig. 5D,F; Table 1) without affecting cell-surface expression of the Flag-Mclr (Fig. 5E,G; Table 1). As a control, medium conditioned by insect cells infected with an irrelevant baculovirus was subjected to procedures similar to those used to purify Agrp; we found that the control preparation had no effect on HA-Agouti binding (Fig. 5C; Table 1). These findings show that similarity between Agouti protein and Agrp includes their binding sites, and highlight the 20 residues shared between mature Agouti protein and Agrp, 10 of which are cysteine, as critical for melanocortin receptor interaction. It should be noted that in previous studies of $\alpha-\mathrm{MSH}$-induced CAMP accumulation, we found that Agrp was a potent antagonist of the MC3R and M C4R, but had little effect on the MC1R (OIImann et al. 1997). The apparent disparity between those results and the binding studies described here may relate to structural differences between the mouse Mclr and human MC1R, or to the phenomenon of spare receptors, whereby maximal effects of an agonist on function occur when only a fraction of the receptors are occupied. In addition, Agrp may not bind the M clr as avidly as A gouti protein, because a few cells weakly positive for HAAgouti could be detected after incubation with micromolar concentrations of Agrp, whereas binding of HAAgouti was completely abolished by $250 \mathrm{~nm}$ native Agouti protein (Table 1, experiment V). 
Table 1. Summary of binding experiments with epitope-tagged Agouti protein

\begin{tabular}{|c|c|c|c|c|c|c|}
\hline Exp. $^{a}$ & Receptor $^{b}$ & Ligand $^{b}$ & Competitor $^{\mathrm{b}}$ & $\begin{array}{l}\text { Special } \\
\text { Cond. }{ }^{\mathrm{C}}\end{array}$ & $\begin{array}{l}\text { Anti- } \\
\text { Flag }^{d}\end{array}$ & $\begin{array}{l}\text { Anti- } \\
H^{d}\end{array}$ \\
\hline \multirow[t]{8}{*}{ I } & GFP only & 25 nм HA-Agouti & none & $16^{\circ}$ & N.A. & no \\
\hline & $\mathrm{Mclr}$ & 25 nм HA-Agouti & none & $16^{\circ}$ & N.A. & yes \\
\hline & Mclr & 25 nм HA-Agouti & excess Agouti ${ }^{\mathrm{e}}$ & $16^{\circ}$ & N.A. & no \\
\hline & Mclr & $25 \mathrm{~nm} \mathrm{HA}-$ Agouti & $2 \mu \mathrm{M} \alpha-\mathrm{MSH}$ & $16^{\circ}$ & N.A. & no \\
\hline & Flag-M clr & none & none & $16^{\circ}$ & yes & N.D. \\
\hline & Flag-M clr & 25 nм HA-Agouti & none & $16^{\circ}$ & yes & yes \\
\hline & Flag-Mclr & 25 nм HA-Agouti & excess Agouti & $16^{\circ}$ & N.D. & no \\
\hline & Flag-Mclr & 25 nм HA-Agouti & $2 \mu \mathrm{M} \alpha-\mathrm{MSH}$ & $16^{\circ}$ & yes & no \\
\hline \multirow[t]{8}{*}{ II } & Mclr & none & none & none & NA & no \\
\hline & $\mathrm{Mclr}$ & 25 nм HA-Agouti & none & none & N.A. & yes \\
\hline & Mclr & 25 nм HA-Agouti & $2 \mu \mathrm{M} \alpha-\mathrm{MSH}$ & none & N.A. & no \\
\hline & Mclr & 25 nм HA-Agouti & $2 \mu \mathrm{m}$ bombesin & none & N.A. & yes \\
\hline & Mclr & 25 nм HA-Agouti & none & unfix. $^{f}$ & N.A. & no \\
\hline & $\mathrm{Mclr}$ & 25 nм HA-Agouti & none & $37^{\circ}$ & N.A. & yes \\
\hline & Flag-B2AR & none & none & none & yes & no \\
\hline & Flag-B2AR & 25 nм HA-Agouti & none & none & N.D. & no \\
\hline \multirow[t]{5}{*}{ III } & Flag-M clr & 25 nм HA-Agouti & none & $5 \mathrm{hr}$ & N.D. & yes \\
\hline & Flag-Mclr & 25 nм HA-Agouti & $2 \mu \mathrm{M} \alpha-\mathrm{MSH}$ & $5 \mathrm{hr}$ & N.D. & no \\
\hline & Flag-M clr & 25 nм HA-Agouti & $2 \mu \mathrm{M}$ N DP-MSH & $5 \mathrm{hr}$ & yes & no \\
\hline & M elanophores ${ }^{\mathrm{g}}$ & none & none & none & N.D. & no \\
\hline & Melanophores & 25 nм HA-Agouti & none & none & N.D. & no \\
\hline \multirow[t]{3}{*}{ IV } & Flag-M clr & none & none & none & N.D. & no \\
\hline & Flag-Mclr & 5 nм HA-Agouti & none & none & N.D. & yes $^{\text {h }}$ \\
\hline & Flag-M clr & 25 nм HA-Agouti & none & none & yes & yes \\
\hline \multirow[t]{7}{*}{ V } & Flag-Mclr & none & none & none & N.D. & $0 / 110$ \\
\hline & Flag-Mclr & 33 nм HA-Agouti & none & none & yes & $92 / 106$ \\
\hline & Flag-M clr & 33 nм HA-Agouti & 250 nм Agouti & none & N.D. & $0 / 90$ \\
\hline & Flag-M clr & 33 nм HA-Agouti & $10 \mu \mathrm{m}$ Agouti & none & N.D. & $0 / 101$ \\
\hline & Flag-Mclr & 33 nм HA-Agouti & Agrp control & none & N.D. & $87 / 104$ \\
\hline & Flag-Mclr & 33 nм HA-Agouti & $6 \mu \mathrm{M} A \operatorname{grp} A+B$ & none & N.D. & $4 / 100^{i}$ \\
\hline & Flag-M clr & 33 nм HA-Agouti & $2 \mu \mathrm{M}$ Agrp C & none & N.D. & $2 / 106^{i}$ \\
\hline \multirow[t]{8}{*}{ VI } & Flag-M clr & none & none & none & $87 / 102$ & $0 / 100$ \\
\hline & Flag-M clr & 25 nм HA-Agouti & none & none & $89 / 114$ & $82 / 100$ \\
\hline & Flag-M clr & $25 \mathrm{~nm} \mathrm{HA}$-A gouti & 500 пм Agouti & none & $87 / 104$ & $0 / 100$ \\
\hline & Flag-Mclr & 25 nм HA-Agouti & 250 nм $\alpha-M S H$ & none & $93 / 109$ & $0 / 106$ \\
\hline & Flag-M clr & 25 nм HA-Agouti & 400 nм Agrp C & none & $91 / 103$ & $4 / 103^{i}$ \\
\hline & Flag-M clr & 25 nм HA-Agouti & $1 \mu \mathrm{M}$ Agrp $A+B$ & none & $84 / 100$ & $8 / 103^{i}$ \\
\hline & Flag-M clr & 25 nм HA-Agouti & Agrp control & none & N.D. & $91 / 113$ \\
\hline & Flag-M clr & 25 nм HA-Agouti & $2 \mu \mathrm{m}$ bombesin & none & N.D. & $73 / 102$ \\
\hline
\end{tabular}

asix representative experiments are depicted, from a total of 151 slides, in which each condition was tested at least twice, but usually four to five times.

${ }^{b}$ Expression plasmids for the Mclr, the Flag-Mclr, or the Flag-B2AR were cotransfected with a 10-fold reduced molar ratio of an expression plasmid for GFP and binding of HA-Agouti to transfected cells in the presence or absence of various competitors was determined, as described in Materials and Methods.

${ }^{\mathrm{C}} \mathrm{All}$ binding studies were carried out for $3 \mathrm{hr}$ at $4^{\circ}$ unless otherwise indicated.

${ }^{\mathrm{d}}$ Results of most binding experiments are described qualitatively (yes or no), based on whether or not strong immunofluorescent signal was present in multiple cel Is after examining at least five microscopic fiel ds. For experiments $V$ and VI, attempts were made to provide a semiquantitative estimate by describing the number of strongly positive immunofluorescent cells/number of GFP-expressing cells examined. (N.A.) N ot applicable; (N.D.) not determined.

ePartially purified A gouti protein was used as competitor for initial experiments; its concentration was not determined precisely but represented $>100$-fold molar excess. Experiments with a defined Agouti protein concentration used a preparation $>99 \%$ pure.

${ }^{f}$ (U nfixed) As described in M aterials and M ethods, A gouti Protein-Binding Assay, except cells were not treated with formal dehyde prior to incubation with the primary antibody.

gXenopus melanophores were used instead of 293T cells.

${ }^{\mathrm{h}}$ The number of cells staining with the anti-HA antibody was similar in experiments that compared 5 to $25 \mathrm{nM} \mathrm{HA}-\mathrm{Agouti}$, but the strength of the immunofluorescent signal was reduced at the lower concentration.

'The few cells designated as anti-HA positive exhibited very weak immunofluorescent signals. 


\section{Additions : \\ 25 nM HA-Agouti $+250 \mathrm{nM}$ a-MSH}

25 nM HA-Agouti + Agrp Control

\section{5 nM HA-Agouti +980 nM Agrp forms A/B}

\section{5 nM HA-Agouti +380 nM Agrp form C}
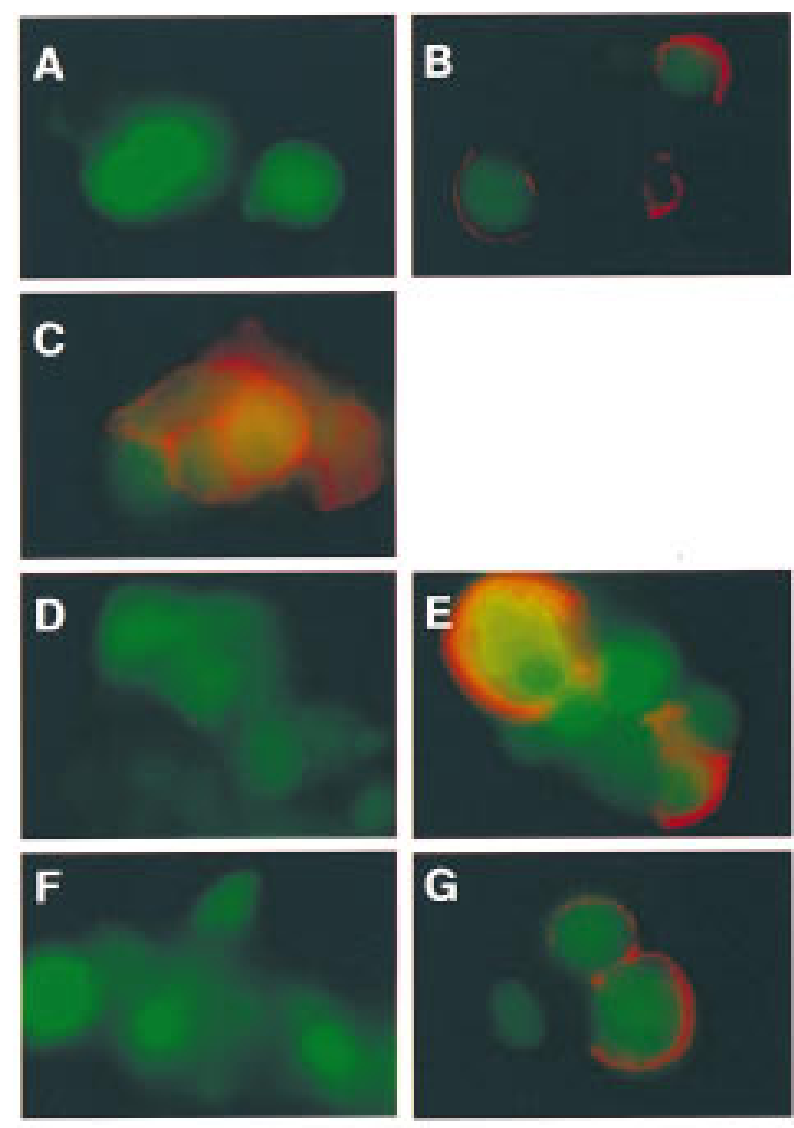

$1^{\circ}$ AB: Anti-HA

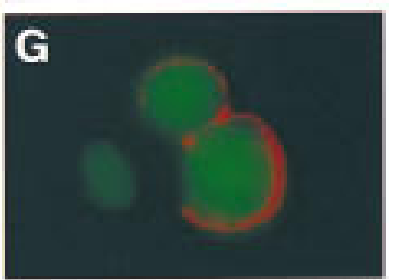

$1^{\circ} \mathrm{AB}$ : Anti-FLAG

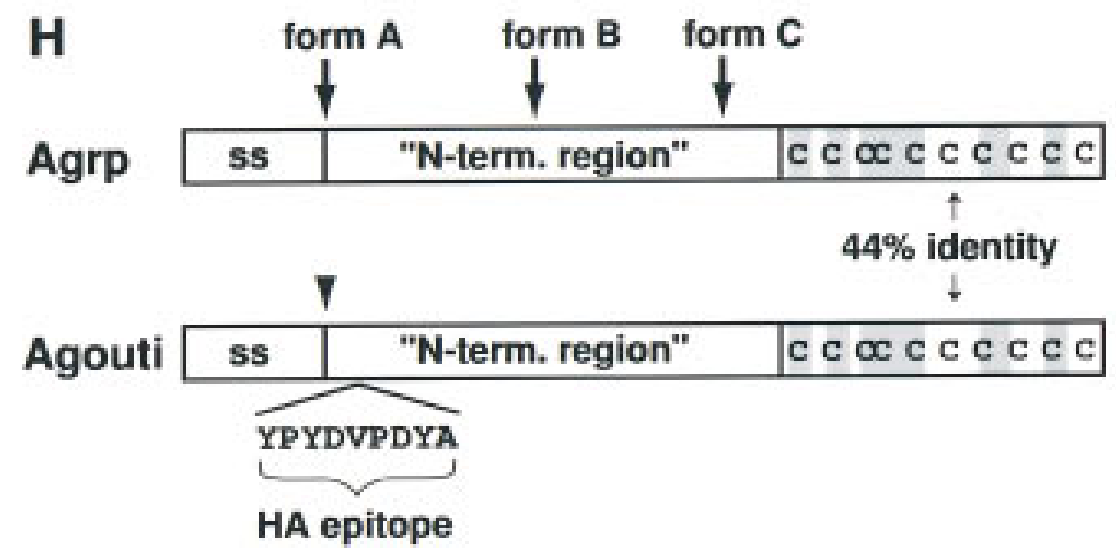

Figure 5. Effects of Agrp and $\alpha-\mathrm{MSH}$ on Agouti protein binding. 293T cells expressing GFP and the Flag-M clr were incubated at $4^{\circ} \mathrm{C}$ in $25 \mathrm{~nm} \mathrm{HA}$-Agouti with the following additions: $250 \mathrm{nM} \alpha-\mathrm{MSH}(\mathrm{A}, \mathrm{B}), 980$ nM Agrp forms $A+B(D, E), 380$ nм Agrp form $C(F, G)$, or control protein for Agrp purification (C). Binding of HA-A gouti or expression of the Flag-M clr was detected by immunofluorescence with anti-HA $(A, C, D, F)$ or anti-Flag $(B, E, G)$ antibodies as described in $M$ aterials and $M$ ethods. Green staining represents GFP expression; red staining represents bound $\mathrm{HA}-\mathrm{Agouti}$ $(A, C, E, G)$ or receptor expression $(B, E, G)$. All panels represent experiments summarized in Table 1. (H) Diagram of Agrp and Agouti protein indicating the signal sequence (ss), placement of the HA epitope in HA-Agouti, the different forms of Agrp, and amino acid similarity between Agrp and Agouti, which is confined entirely to the cysteine-rich carboxyl terminus.
The effects of Agouti on pigmentation in vivo require a functional Mclr

The studies described above indicate that Agouti protein interacts directly with the Mclr, but it is possible that Agouti protein may bind to and signal through additional cell-surface molecules present on pigment cells. To address this question, we asked whether the coat color phenotype of animals carrying a gain-of-function Agouti allele, lethal yellow $\left(A^{y}\right)$, was modified by the presence of a loss-of-function Mclr allele, recessive yellow $\left(M c l r^{\mathrm{e}}\right)$. On most genetic backgrounds, this analysis is inconclusive because the phenotypes of each single mutant are very similar. Several observations, however, (for review, see Silvers 1979b) suggest that a hypomorphic mutation at the al bino (c) locus, chinchilla ( ${ }^{\mathrm{ch}}$ ), produces a sensitized background in which the coat color phenotypes caused by $A^{y}$ and $M c 1 r^{e}$ can be distinguished. By use of a consistent strain background, C57BL6/J, we confirmed this observation: $A^{y} / a ; c^{c h} / c^{c h}$ mice are cream colored, 
in contrast to $\mathrm{Mclr} / \mathrm{Mclr} r^{\mathrm{e}} ; \mathrm{c}^{\mathrm{ch}} / \mathrm{C}^{\mathrm{ch}}$ mice that are pale yellow with black ticking (Fig. 6B; Table 2).

We constructed breeding pairs that segregated lethal yellow and recessive yellow, and found that all animals with the cream colored phenotype were $A^{y} / a ;+/ M c l r$; $c^{c h} / c^{c h}$ or $A^{y} / a ; H+; c^{c h} / c^{c h}$ whereas animals with the pale yellow plus eumelanin phenotype were $A^{y} / a$; $\mathrm{Mclr} / \mathrm{Mclr}$; $\mathrm{c}^{\mathrm{ch}} / \mathrm{c}^{\mathrm{ch}}$ or a/a; Mclre/Mclre; $\mathrm{c}^{\mathrm{ch}} / \mathrm{c}^{\mathrm{ch}}$ (Fig. $6 \mathrm{~B}, \mathrm{~T}$ able 2). There are several possibilities to expl ain the difference in coat color phenotypes between $A^{y}$ and $\mathrm{Mclr}^{\mathrm{e}}$ (see below). Regardless of the exact mechanism, our results show that the effects of $A^{y}$ on pigmentation in vivo require a functional $\mathrm{Mclr}$, and, therefore, argue against the presence of an additional melanocyte receptor for Agouti protein.

\section{Discussion}

Genetic and transplantation studies carried out several decades ago first suggested the possibility that gene products encoded by Agouti and Extension (now renamed as the Mclr) might interact as ligand and receptor, respectively, because both genes affect the balance between black and yellow pigment synthesis, and because Extension was melanocyte autonomous whereas Agouti was not (for review, see Silvers 1979a). Recessive alleles of Extension, however, produce pigmentation phenotypes similar to dominant alleles of Agouti, and vice versa, which indicated that Agouti protein must inhibit, rather than activate, the Extension gene product.

More recently, molecular genetic and pharmacologic studies have shown that Agouti protein antagonizes the Mclr (Lu et al. 1994; Blanchard et al . 1995; Willard et al. 1995; Y ang et al. 1997), but the biochemical mechanism by which this takes place has been controversial (Conklin and Bourne 1993; Jackson 1993). In particular, the ability of Agouti protein to elicit cellular responses apparently independent of adenylate cyclase (Hunt and Thody 1995; Siegrist et al. 1996, 1997; Sakai et al. 1997; Suzuki et al. 1997), combined with similarity in cysteine spacing between Agouti protein and invertebrate toxins that affect cal cium channels (Olivera et al. 1991; Quistad and Skinner 1994; Zemel et al. 1995), has led to uncertainty regarding the identity of the Agouti protein receptor or receptors. Our results show that the Mclr encodes a receptor for Agouti protein, and that a functional $\mathrm{Mclr}$ is required for Agouti signal ing in vivo. Furthermore, our results suggest that the effects of A gouti protein cannot be explained solely by inhibition of $\alpha-\mathrm{MSH}$ binding. These results are likely to apply to homologs of Agouti and the Mclr that normally regulate other biologic processes, and have general implications for understanding melanocortin-receptor signaling.

\section{The Mclr is an Agouti receptor}

Previous studies carried out by us and others have shown that binding of the radiolabeled melanocortins NDP$\mathrm{MSH}$ or ACTH to whole cells can be inhibited by recombinant Agouti protein ( $\mathrm{Lu}$ et al. 1994; Blanchard et al. 1995; Siegrist et al. 1997; Yang et al. 1997). As shown here, expression of the Mclr provides a binding site for Agouti protein that can be blocked by $\alpha-\mathrm{MSH}$, which strongly suggests that Agouti protein is a ligand for the Mclr. Although the immunofluorescence assay precludes a quantitative measurement of binding affinity, Agouti protein binding is detectable after incubation in 5
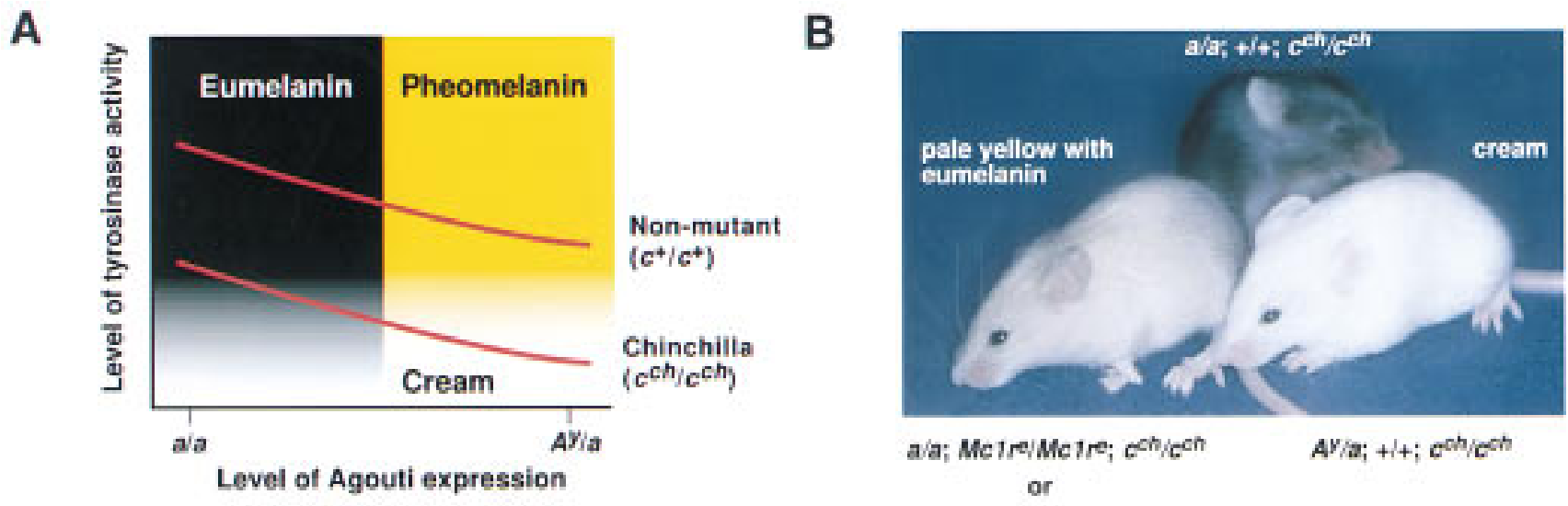

AY/g; Mctre/Mctre; $c^{\text {eh/ } / C^{2 h}}$

Figure 6. Interaction between $A^{y}$ and the $M c 1 r^{e}$ mutations on a chinchilla ( $\mathrm{C}^{\mathrm{ch}} / \mathrm{C}^{\mathrm{ch}}$ ) background. (A) Diagram of the relationship between Agouti expression and tyrosinase activity based on Geschwind (1966), Kobayashi et al. (1995), M ovaghar (1989), and Prota et al. (1995), and as modified from Barsh (1996). During the switch from eumelanin to pheomelanin production caused by increased Agouti expression, tyrosinase activity is gradually downregulated. The exact biochemical mechanism of the switch is not clear, but may be related to abrupt cessation of other melanogenic proteins. Because tyrosinase catalyzes the rate-limiting step for production of both pigment types, animals carrying a point mutation that impairs tyrosinase activity, such as chinchilla, make very little or no pigment in the presence of high levels of A gouti, and appear cream-colored. (B) Photograph of animals that carry various combinations of coat color mutations (see text and Table 2 for further explanation). 
Table 2. Effects of the $A^{y}$ and $M c l r^{e}$ mutations on a chinchilla $\left(c^{\mathrm{ch}} / \mathrm{C}^{\mathrm{ch}}\right)$ background

\begin{tabular}{|c|c|c|c|c|c|}
\hline \multirow[b]{2}{*}{ Cross } & \multirow[b]{2}{*}{ Phenotype $^{a}$} & \multirow[b]{2}{*}{$\mathrm{No} .^{\mathrm{b}}$} & \multicolumn{3}{|c|}{ Genotype $^{b}$} \\
\hline & & & Agouti & Mclr & $\operatorname{Tyr}(c)^{c}$ \\
\hline$A^{y} / a ;+t+; / c^{c h}$ & yellow & & $\mathrm{A}^{\mathrm{y} / \mathrm{a}}$ & $H+$ & $H / c^{c h}$ \\
\hline$\times$ & cream & & $\mathrm{A}^{\mathrm{y} / \mathrm{a}}$ & $H+$ & $\mathrm{c}^{\mathrm{ch}} / \mathrm{c}^{\mathrm{ch}}$ \\
\hline \multirow[t]{2}{*}{$a / a ;+t+c^{c h} / c^{c h}$} & black & & $a / a$ & $H+$ & $H / c^{c h}$ \\
\hline & black & & $a / a$ & $H+$ & $\mathrm{C}^{\mathrm{ch}} / \mathrm{c}^{\mathrm{ch}}$ \\
\hline $\mathrm{a} / \mathrm{a} ;+\mathrm{Mcl} \mathrm{r}^{\mathrm{e}},+/ \mathrm{c}^{\mathrm{ch}}$ & yellow & & $a / a$ & $\mathrm{Mclr}$ e/Mclre & $H+$ or $H / c^{c h}$ \\
\hline$\times$ & pale yellow ${ }^{d}$ & & $a / a$ & $\mathrm{Mclr} / \mathrm{Mclr} r^{\mathrm{e}}$ & $\mathrm{ch}^{\mathrm{ch}} / \mathrm{c}^{\mathrm{ch}}$ \\
\hline \multirow[t]{2}{*}{ ala; $+/ M c l r^{e} ; H c^{c h}$} & black & & $a / a$ & $+1+$ or $+/ \mathrm{Mclr}^{\mathrm{e}}$ & $H+$ or $H / c^{c h}$ \\
\hline & black & & $a / a$ & $\mathrm{H}+$ or $+/ \mathrm{Mcl} r^{\mathrm{e}}$ & $\mathrm{C}^{\mathrm{ch}} / \mathrm{c}^{\mathrm{ch}}$ \\
\hline $\mathrm{A}^{\mathrm{y}} / \mathrm{a} ; \mathrm{Mcl} \mathrm{r}^{\mathrm{e}} / \mathrm{Mcl} \mathrm{r}^{\mathrm{e}} ; \mathrm{c}^{\mathrm{ch}} / \mathrm{c}^{\mathrm{ch}}$ & cream & 9 & $A^{y} / a$ & $+/ M c l r^{e}$ & $\mathrm{ch}^{\mathrm{ch}} / \mathrm{c}^{\mathrm{ch}}$ \\
\hline$x$ & pale yellow ${ }^{d}$ & 9 & $A^{y / a}$ & $\mathrm{Mclr} / \mathrm{Mcl} \mathrm{r}^{\mathrm{e}}$ & $\mathrm{c}^{\mathrm{ch}} / \mathrm{c}^{\mathrm{ch}}$ \\
\hline \multirow{2}{*}{$\mathrm{A}^{\mathrm{y}} / \mathrm{a} ;+/ \mathrm{Mclr} \mathrm{r}^{\mathrm{e}} \mathrm{c}^{\mathrm{ch}} / \mathrm{c}^{\mathrm{ch}}$} & pale yellow ${ }^{d}$ & 9 & $a / a$ & Mclre/Mclre & $\mathrm{ch}^{\mathrm{ch}} / \mathrm{c}^{\mathrm{ch}}$ \\
\hline & black & 7 & $a / a$ & $+/ M c l r^{e}$ & $\mathrm{ch}^{\mathrm{ch}} / \mathrm{c}^{\mathrm{ch}}$ \\
\hline
\end{tabular}

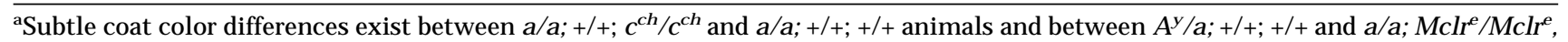
+ + animals.

bPhenotypic classes were tallied, and genotypes were determined using molecular techniques as described in Materials and M ethods only for the last cross, which represents two breeding pairs. Results similar to the first two crosses have been described previously by Feldman (1935) and by Searle and Beechey (1970), respectively.

'The symbol for the al bino locus (c) was recently changed to Tyr; here we refer to the chinchilla mutation with the symbol $c^{\text {ch }}$ rather than $\mathrm{Tyr}^{\mathrm{c}-\mathrm{ch}}$.

${ }^{\mathrm{d}} \mathrm{Mclr} / \mathrm{Mcle}$; $\mathrm{c}^{\mathrm{ch}} / \mathrm{c}^{\mathrm{ch}}$ mice are pale yellow with eumelanin ticking and can easily be distinguished from $\mathrm{cream}-\mathrm{col}_{\mathrm{ored}} \mathrm{A}^{\mathrm{y}} / \mathrm{a} ; \mathrm{c}^{\mathrm{ch}} / \mathrm{c}^{\mathrm{ch}}$ animals by the presence of eumelanin or from yellow $\mathrm{Mclr} / \mathrm{Mcl} \mathrm{r}^{\mathrm{e}} ;+\mathrm{c}^{\mathrm{ch}}$ animals by reduced intensity of pheomelanin.

nм HA-Agouti and can be inhibited by excess native Agouti protein, showing that the binding site we describe is specific and represents a high affinity site.

Even though Agouti protein and $\alpha-\mathrm{MSH}$ inhibit each other's binding, the two molecules may not interact with identical sites on the Mclr. The active portion of Agouti protein contains 40 amino acids and 5 disulfide bridges which, by analogy to other proteins of similar size and cysteine spacing, stabilize a hydrophilic tertiary structure that interacts with one or more extracellular domains of the receptor. In contrast, $\alpha-\mathrm{MSH}$ and other small melanocortin peptides that contain the core sequence His-Phe-Arg-Trp are thought to interact with membrane-spanning portions of the receptor ( $\mathrm{M}$ i wa et al . 1995; Prusis et al. 1995; Haskell-Luevano et al. 1996a,b). A model for the binding of omega-conotoxins, which contain three disulfide bridges with primary sequence spacing identical to Agouti protein, posits interaction with a target receptor macrosite that di rectly blocks access of one or more small molecule agonists to bind their microsites (Olivera et al . 1991). This same model might apply to Agouti protein, Agrp, and melanocortin receptors. Alternatively, Agouti protein and $\alpha-\mathrm{MSH}$ could bind to nonoverlapping sites on the $\mathrm{Mclr}$, yet inhibit each other's binding by inducing an all osteric change in the receptor. Additional mutagenesis studies that focus on melanocortin receptors exhibiting a differential response to Agouti protein or to Agrp (Lu et al. 1994; OIImann et al. 1997; Yang et al. 1997) may help to clarify certain aspects of the interaction between A gouti protein and the Mclr, although a complete understanding will require more detailed information about receptor structure.
Agouti signaling is not equivalent to inhibition of $\alpha$-MSH binding in vitro

Mutually exclusive binding of Agouti protein and $\alpha-\mathrm{MSH}$ to the M clr is consistent with a model of competitive antagonism, whereby Agouti protein would act solely to reversibly displace ligand binding. In Xenopus melanophores, however, which share some, but not all, features of melanocortin signaling with mammalian cells, our observations indicate Agouti protein has effects beyond simply inhibiting the binding of $\alpha-\mathrm{MSH}$.

Specifically, Agouti protein alters the slope of the dose-response curve for $\alpha$-M SH-induced pigment dispersion, and preincubation in Agouti protein increases its ability to inhibit melanocortin activity. These findings suggest that Agouti protein not only inhibits the binding of agonists, but al so alters the interaction of mel anocortin receptors with intracellular effectors. The time- and temperature- dependence of Agouti protein activity revealed in the preincubation experiments might be explained by certain types of post-translational modifications that decrease receptor coupling (for review, see Lefkowitz et al. 1993). Alternatively, Agouti protein could cause internalization of the melanophore $\alpha-\mathrm{MSH}$ receptor, as Eberle and colleagues have reported for the Mclr in B16 melanoma cells (Siegrist et al. 1996).

The conclusion that Agouti protein is not a simple competitive antagonist of melanocortin receptors may help to explain the discrepancy between estimates of Agouti protein affinity based on functional compared with binding assays (Lu et al . 1994; Blanchard et al . 1995; Willard et al. 1995; Kiefer et al. 1997; Yang et al. 1997). Furthermore, the observation that Agouti protein does 
not act solely by inhibiting the binding of $\alpha-\mathrm{MSH}$ raises the possibility that control of melanocortin receptor signaling does not require the presence of melanocortins in vivo. Injection of $\alpha-\mathrm{MSH}$ near growing hairs induces eumelanin production (Geschwind 1966), but it is not known whether physiologic levels of melanocortin peptides are present in the hair follicles when transient expression of Agouti during normal hair growth gives rise to a banded pigmentation pattern. In Xenopus melanophores, the effects of Agouti protein can be detected only in the presence of melanocortin peptides. In mammalian skin, however, binding of Agouti protein to the Mclr may be sufficient to al ter receptor signaling and produce the phenotypic effects of Agouti in the absence of exogenous melanocortins.

\section{The Mclr is required for Agouti signaling in vivo}

The lethal yellow $\left(A^{y}\right)$ and recessive yellow $\left(M c l r^{\mathrm{e}}\right) \mathrm{mu}$ tations usually produce a similar coat color, but we found that reduced activity of tyrosinase caused by the chinchilla $\left(c^{c h}\right)$ mutation enhanced the difference in pigmentation phenotypes between lethal yellow and recessive yellow mice. Our comparisons were carried out on a uniform genetic background provided by the C57BL/6J strain; similar results in a mixed genetic background were reported in Mouse News Letters by Searle and Beechey (1970). Differences in pigmentation phenotypes caused by lethal yellow and recessive yellow have also been uncovered in animals heterozygous for the albino $\left(T y r^{C}\right)$ mutation, or in animals homozygous for dilute

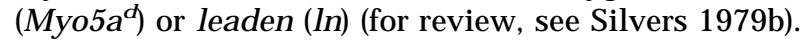

The different coat color phenotypes of $A^{y} / a ; c^{c h} / c^{c h}$ and $\mathrm{Mclr} / \mathrm{Mclr}$; $\mathrm{C}^{\mathrm{ch}} / \mathrm{C}^{\mathrm{ch}}$ mice, cream-colored and pale yellow with black ticking, respectively, indicate that overexpression of Agouti protein is not equival ent to loss of $\mathrm{Mclr}$ signaling. A priori, incomplete inhibition of Mclr signaling by Agouti protein might account for a phenotypic difference between lethal yellow and recessive yellow, but this is unlikely to explain our observations because, in general, $\mathrm{Mcl}$ c signaling is proportionate to tyrosinase activity (Geschwind 1966; M ovaghar 1989; Kobayashi et al. 1995; Prota et al. 1995), and the creamcolored phenotype is caused by a reduction rather than an increase in tyrosinase activity (see Fig. 6A).

Furthermore, the different coat color phenotypes of lethal yellow and recessive yellow are probably not caused by residual $\mathrm{Mclr}$ activity in $\mathrm{Mclr} / \mathrm{Mclr}^{\mathrm{e}}$ mice, because the Mclr ${ }^{\mathrm{e}}$ mutation is caused by a frameshift that gives rise to a truncated protein with no detectable activity in vitro (Robbins et al. 1993; also see below). It is possible that the cream-colored phenotype of $A^{y} / a ; c^{c h} / c^{c h}$ mice comes about because Agouti protein causes the Mclr to couple to an effector other than Gs and adenylate cyclase, in which case Agouti protein should be considered a potential agonist as well as an antagonist of the Mclr.

Regardless, the ability of Agouti protein to cause a cream-colored phenotype in $A^{y} / a ; c^{c h} / c^{c h}$ mice requires a functional $\mathrm{Mclr}$, because $\mathrm{A}^{\mathrm{y}} / \mathrm{a} ; \mathrm{Mclr} / \mathrm{Mclr} \mathrm{r}^{\mathrm{e}} ; \mathrm{c}^{\mathrm{ch}} / \mathrm{c}^{\mathrm{ch}}$ mice exhibit a different coat color phenotype that is in- distinguishable from that observed in $\mathrm{Mclr}$ / Mclre; $\mathrm{c}^{\mathrm{ch}} /$ $\mathrm{C}^{\mathrm{ch}}$ mice. These findings reinforce the conclusion based on in vitro studies that the Mclre mutation causes a complete loss of function (Robbins et al. 1993), and, more importantly, show that the ability of Agouti protein to alter pigmentation in vivo is mediated by the $\mathrm{Mclr}$ and not by a receptor specific for Agouti protein.

\section{Concluding remarks}

Control of $\mathrm{G}$ protein-coupled receptor signaling in most biological systems is determined primarily by agonist availability. As endogenous antagonists, Agouti protein and Agouti-related protein offer some unique advantages for regulation of melanocortin receptor signaling. The limited tissue distribution and biochemical specificity of Agouti protein allows individual regulation of melanocortin receptor subtypes that could not be achi eved by regulating agonist transcription, because melanocortin peptides and $\beta$-endorphin are circulating molecules derived from a single precursor, pro-opiomelanocortin (Pomc). In addition, the studies described here suggest a viewpoint whereby Agouti protein and $\alpha-\mathrm{MSH}$ function as independent ligands that transduce opposite signals through the $\mathrm{Mclr}$, yet also inhibit each other's binding to the Mclr. Both viewpoints, that of endogenous antagonist and that of independent ligand, hel p to explain why genetic control of the balance between eumelanin and pheomelanin is attributable mostly to alleles of Agouti or the Mclr rather than Pomc, because transcriptional control of $\alpha-\mathrm{MSH}$ would likely affect all melanocortins as well as $\beta$-endorphin, and because Agoutimediated signaling through the $\mathrm{Mclr}$ may not require the presence of $\alpha-\mathrm{MSH}$.

To date, homologs of Agouti or Agrp have been found only in mammals, although melanocortins are widely distributed among vertebrates including avians and cartilaginous fish (for review, see Dores et al. 1990). Previously, we have suggested that an, as yet undiscovered, Agouti homolog may be responsible for dorsal-ventral differences in amphibian pigmentation Nrieling et al. 1994), a speculation that is supported by the ability of Agouti protein and Agouti-related protein derived from mice or humans to inhibit $\alpha-\mathrm{MSH}$-induced pigment dispersion in Xenopus melanophores (Ollmann et al. 1997). Given the similarity in cysteine spacing shared between Agouti and insect neurotoxins, it is possible that a common precursor of these proteins was adapted to regulate melanocortin receptor si gnaling in primitive vertebrates. From this perspective, it will be interesting to determine the point at which Agouti and Agouti-related protein evolved from a common ancestor, because this may reflect adaptation of melanocortin receptor signaling for peripheral functions such as pigmentation, and central functions, such as feeding behavior.

\section{Materials and methods}

Xenopus melanophore culture and pigment dispersion assay

Xenopus melanophores were grown at $27^{\circ} \mathrm{C}$ in $50 \% \mathrm{~L}-15$ media 
(Specialty M edia, Lavallete, NJ), supplemented with $20 \%$ heatinactivated fetal calf serum, $1 \mathrm{~mm}$ L-glutamine, penicillin, and streptomycin; the media had been conditioned previously by use of Xenopus fibroblasts as described by Potenza and Lerner (1992). The pigment dispersion assay developed by Lerner and colleagues (Potenza and Lerner 1992) is based on the ability of agents that cause a decrease or increase in intracellular CAM P levels to produce a dose-dependent aggregation or dispersion, respectively, of intracellular pigment granules. Because pigment granules are neither fully aggregated nor dispersed in the absence of any drug, pretreatment of the cells with melatonin to aggregate pigment granules increases the range and sensitivity of the assay for detecting agents such as $\alpha-\mathrm{MSH}$ that disperse pigment granules. For a typical assay, cells were plated in 96well plates at 25,000 cells/well 24-48 hr beforehand, washed briefly with $250 \mu \mathrm{l} /$ well assay buffer (70\% L-15 media; 0.1\% BSA), $40 \mu \mathrm{l} /$ well assay buffer was then added, followed by $40 \mu \mathrm{l} /$ well assay buffer that contained $2 \mathrm{~nm}$ of melatonin (Sigma, St. Louis, MO) to provide a final melatonin concentration of $1 \mathrm{~nm}$. After a $45 \mathrm{~min}$ incubation to aggregate pigment granules, the optical density of each well was measured at 650 $\mathrm{nm}\left(O D_{\text {initial }}\right)$ to provide a baseline optical density reading. A gouti protein samples to be assayed were added at $40 \mu \mathrm{l} /$ well followed by the addition of various concentrations of $\alpha-\mathrm{M} \mathrm{SH}$ or forskolin at $40 \mu \mathrm{l} /$ well. All additions were made in assay buffer supplemented with $1 \mathrm{~nm}$ of melatonin to maintain a constant concentration of melatonin during the assay. Optical density at $650 \mathrm{~nm}$ was then determined at multiple time points from 30 to $355 \mathrm{~min}\left(O D_{\text {final }}\right)$. All steps were carried out at room temperature unless noted otherwise. A unitless parameter defined as degree of pigment dispersion was calculated as described by Potenza and Lerner (1992), $\left(O D_{\text {final }}-O D_{\text {initial }}\right) / O D_{\text {final }}$, which creates an internal standard for each well $\left(O D_{\text {initial }}\right)$ and scales the maximal degree of pigment dispersion to 1 . The effects of 1 $\mathrm{mm}$ melatonin occasionally increase during the course of the assay, which gives rise to negative values for the degree of pigment dispersion. Optical density at $650 \mathrm{~nm}$ of melanophores was measured with a Vmax kinetic microplate reader ( $M$ olecuIar Devices, Menlo Park, CA) in endpoint mode, and data was transferred electronically to a Microsoft Excel spreadsheet for analysis. Graphing and curve fitting of dose-response curves was carried out with DeltaGraph (DeltaPoint, M onterey, CA), with a four parameter logistic equation, $y=a+\left[(b-a) /\left(1+\left(10^{c} /\right.\right.\right.$ $\left.\left.\left(10^{\times}\right)^{d}\right)\right]$; where $a=$ minimum, $b=$ maximum, $c=$ half-maximal $\times$ value, and $d=$ slope.

Generation and purification of recombinant Agouti proteins

A 527-bp EcoRI fragment that contains the mouse Agouti ORF but lacks a polyadenylation signal [residues 122-648 in Miller et al . (1993)] was modified by insertion of a 519-bp mouse genomic fragment that contained the polyadenylation signal, with a BssHII site 15 bp $3^{\prime}$ of the termination codon. The entire fragment was inserted into the bacul ovirus transfer vector pVL1393 (Pharmingen, San Diego). For HA-tagged mouse Agouti protein, the 9-amino-acid HA epitope YPYDVPDYA was placed 5 amino acids downstream of the signal sequence cleavage site (Fig. $5 \mathrm{H}$ ) by inserting a double-stranded DNA fragment, created by annealing together the oligonucleotides $5^{\prime}$-TCGAATACCCGTACGACGTCCCCGATTACGCAC-3' and 5'-TCGAGTGCGTAATCGGGGACGTCGTACGGGTAT-3', into a Xhol site that spans codons 26-27. The CDN As for native Agouti or HAtagged Agouti were cloned into the EcoRI site of baculovirus transfer vector pVL1393 (Pharmingen).

For native Agouti protein, high-titer recombinant baculovirus was produced by standard methods and added at a 60-fold dilu- tion to 6.7 liters of Trichoplusia ni cells grown in suspension to $4 \times 10^{6} \mathrm{cells} / \mathrm{ml}$ in Ex-Cell 401 media (JR Scientific, Woodland, CA). Conditioned media harvested $50 \mathrm{hr}$ after infection was centrifuged at $10,000 \mathrm{~g}$ for $60 \mathrm{~min}$, then applied at $10 \mathrm{ml} / \mathrm{min}$ to a $1.5 \times 7.3-\mathrm{cm}$ SP Sepharose Fast Flow cation exchange column. The column was washed with $64 \mathrm{ml}$ of $50 \mathrm{~mm}$ Bicine, at pH 9.0; $100 \mathrm{~mm} \mathrm{NaCl}$, then eluted with a $250 \mathrm{ml}$ of $\mathrm{N} \mathrm{aCl}$ gradient (100 $\mathrm{mm}-600 \mathrm{~mm} \mathrm{NaCl}$ in $50 \mathrm{~mm}$ bicine, at $\mathrm{pH} 9.0$ ). Flowthrough, wash, and eluate fractions (6.4 $\mathrm{ml} /$ fraction) were diluted in meIanophore assay buffer at 1:10, 1:10, and 1:100, respectively, and tested in the Xenopus melanophore assay for inhibition of $\alpha$ $\mathrm{MSH}$-induced pigment dispersion. A single peak of $\alpha-\mathrm{MSH}$ inhibitory activity eluted from the cation exchange column at $\sim 470 \mathrm{~mm} \mathrm{NaCl}$, and is described below as the cation exchange product. Active fractions were buffer exchanged into $10 \mathrm{~mm}$ CAPS, at pH 10.5; $10 \mathrm{~mm} \mathrm{NaCl}$ with a $210 \mathrm{ml}$ Sephadex G-25 column, then applied to a $1 \mathrm{ml}$ of HiTrap Q anion exchange column. The anion exchange column was washed with $5 \mathrm{ml}$ of $10 \mathrm{~mm}$ CAPS at $\mathrm{pH} 10.5$ and $10 \mathrm{~mm} \mathrm{~N} \mathrm{aCl}$, then eluted with a 20 $\mathrm{ml}$ of $\mathrm{NaCl}$ gradient $(10 \mathrm{~mm}-450 \mathrm{~mm} \mathrm{NaCl}$ in $10 \mathrm{~mm}$ CAPS, at $\mathrm{pH}$ 10.5), followed by $5 \mathrm{ml}$ of $10 \mathrm{~mm}$ CAPS, at $\mathrm{pH}$ 10.5; $450 \mathrm{~mm}$ $\mathrm{N} \mathrm{aCl}$, and $5 \mathrm{ml}$ of $10 \mathrm{~mm} \mathrm{CAPS}$, at $\mathrm{pH} 10.5 ; 1 \mathrm{M} \mathrm{N} \mathrm{aCl}$. Wash and eluate fractions ( $0.5 \mathrm{ml} /$ fraction) were diluted in melanophore assay buffer at 1:200; $\alpha$-M SH inhibitory activity was detected in the flowthrough, described bel ow as anion exchange product 1 , and in a peak eluting in $\sim 150 \mathrm{mM} \mathrm{NaCl}$, described below as anion exchange product 2 . Active fractions were dialyzed into $20 \mathrm{~mm}$ PIPES, at $\mathrm{pH} 6.8 ; 50 \mathrm{~mm} \mathrm{NaCl}$ (storage buffer), flash frozen, and stored at $-70^{\circ} \mathrm{C}$. The final yield of Agouti protein from 6.7 liters of conditioned media was $8.1 \mathrm{mg}$ of anion exchange product 1 and 1.2 mg of anion exchange product 2 . Chromatographic media were obtained from Pharmacia (Piscataway, $\mathrm{NJ}$ ), and all purification steps were carried out at $4^{\circ} \mathrm{C}$.

One-microgram samples of conditioned media, cation exchange product, anion exchange product 1 , and anion exchange product 2 were separated by SDS-PAGE on a $4 \%-20 \%$ gradient gel and detected by silver staining, as shown in Figure 1 . On the basis of a sensitivity of $2-5 \mathrm{ng} / \mathrm{band}$, we estimate that anion exchange products 1 and 2 are $\geqslant 99 \%$ pure. Amino-terminal sequencing identified both products as mouse Agouti protein cleaved at the predicted signal sequence cleavage site between amino acids 22 and 23.

HA-tagged Agouti protein was produced in baculovirus by use of methods identical to those described above, but was not subjected to the final anion exchange step.

\section{Expression of the Mclr and Flag-Mclr}

The mouse Mclr expression vector was constructed by inserting a 947-bp fragment that contained the mouse M clr proteincoding region, generously provided by Dr. Linda Rehfuss (KlineBeecham, Philadel phia, PA), into BamHI-Xbal sites of the vector pcDNA3 (Invitrogen, San Diego, CA). For construction of the Flag-Mclr expression vector, a 132-bp fragment that encodes a cleavable signal sequence followed by the Flag epitope was fused to the Mclr protein-coding sequence with a Tth111l site that lies immediately $5^{\prime}$ of the M clr initiation codon. The 132-bp fragment was derived by PCR of the plasmid Sfbeta2 (Guan et al. 1992) with the oligonucleotide primers 5'-ATACTCAAGCTTGAATTCGAGCTCG-3' and 5'-GCTCTAGAGCCGGCGTCATCATCGTCCTTG-3', and has been shown to enhance surface expression of adrenergic receptors, which, like melanocortin receptors, lack an amino-terminal-cleavable signal sequence (Guan et al. 1992).

Receptor plasmids were transiently expressed in 293T cells by use of calcium phosphate transfection according to standard 
methods. Cells were plated at $9 \times 10^{5}$ cells/60-mm dish $16-20$ $\mathrm{hr}$ beforehand, incubated with fresh media for 2-4 hr, then exposed to a mixture of calcium phosphate and $20 \mu \mathrm{g}$ of plasmid DNA encoding the M Clr, the Flag-M clr, or a control Flag- $\beta 2$ adrenergic receptor, generously provided by Dr. Brian Kobilka (Stanford U niversity School of M edicine, CA). Each transfection al so included $2 \mu \mathrm{g}$ of an expression plasmid encoding GFP. After 12-16 hr, the cells were rinsed with $\mathrm{CaCl}_{2}$ - and $\mathrm{M} \mathrm{gCl}_{2}$-containing phosphate-buffered sal ine (PBS), then incubated in fresh media for an additional $48 \mathrm{hr}$ prior to the binding assay.

\section{Agouti protein-binding assay}

HA-Agouti binds avidly to the extracel lular matrix and to plastic, and, therefore, we carried out the binding assay on cells in suspension. Cells that had been transfected previously with a receptor expression plasmid were removed from the dish by rinsing with binding buffer (90\% DMEM ; 25 mM HEPES, at pH 7.4; $0.2 \%$ ovalbumin), washed and resuspended in binding buffer at $\sim 2 \times 10^{6}$ cells $/ \mathrm{ml}$, and $100-\mu \mathrm{l}$ aliquots were placed in polystyrene tubes. To each tube, competitor protein (Agouti protein, Agrp, $\alpha-\mathrm{MSH}$, bombesin, or buffer control; see Table 1 for concentrations) was added in $50 \mu \mathrm{l}$ of binding buffer, followed by an additional $50 \mu \mathrm{l}$ of binding buffer that contained HA-A gouti to achieve a final concentration of $5 \mathrm{~nm}-33 \mathrm{~nm} \mathrm{HA}-$ A gouti. After $3 \mathrm{hr}$ at $4^{\circ} \mathrm{C}, 3 \mathrm{ml}$ of cold PBS was added, cells were washed three times with $3.5 \mathrm{ml}$ of PBS, then resuspended in 400 $\mu \mathrm{l}$ of PBS to which $400 \mu \mathrm{l}$ of $4 \%$ formal dehyde in PBS was then added. After a $15 \mathrm{~min}$ fixation at room temperature, cells were washed twice with $3.5 \mathrm{ml}$ of PBS, then resuspended in $3.5 \mathrm{ml}$ of $5 \%$ goat serum in PBS. After a 60 min incubation to block nonspecific binding, cells were centrifuged and resuspended in $300 \mu \mathrm{l}$ of $5 \%$ goat serum in PBS that contained a 1:500 dilution of primary antibody (16B12 anti-HA, BabCO, Richmond, CA; or M 1 Anti-Flag, IBI/Kodak, Rochester, NY), and incubated overnight. Primary antibody was removed by centrifugation and washing three times with $3.5 \mathrm{ml}$ of $5 \%$ goat serum in PBS, then cells were resuspended in $250 \mu \mathrm{l}$ of $5 \%$ goat serum in PBS that contained a 1:300 dilution of secondary antibody, goat antimouse IgG conjugated to Texas Red. After a 60 min incubation, cells were washed four times with PBS, resuspended in residual PBS and mounted on a glass slide with Vectashield mounting media (Vector, Burlingame, CA). Immunofluorescent images were acquired with a Zeiss Axiophot microscope (100 $\times$ objective) and CCD camera with exposure times of $1 \mathrm{sec}$ for Texas Red images and $0.5 \mathrm{sec}$ for GFP images. Texas Red and GFP images were merged in Adobe Photoshop with identical adjustment of brightness and contrast for all images.

\section{Mouse strains, mutations, and breeding experiments}

Mice carrying the lethal yellow $\left(A^{y}\right)$, recessive yellow $\left(M c 1 r^{\mathrm{e}}\right)$, or chinchilla $\left(\mathrm{Tyr}^{\mathrm{c}-\mathrm{ch}}\right)$ mutations were obtained originally from The Jackson Laboratory (Bar Harbor, ME) and are maintained by one of us (M.L. Lamoreux) on the C57BL/6J background. The symbol for chinchilla was recently changed from $\mathrm{c}^{\mathrm{ch}}$ to $\mathrm{Tyr}^{\mathrm{c}-\mathrm{ch}}$, but the older nomenclature has been used here to avoid confusion.

As summarized in Table 2 , the $A^{y}$ or $M c 1 r^{e}$ mutations were first placed on a chinchilla background by a cross with $A^{y} / a$; $H+; H c^{c h}$ or $a / a ; H / M c 1 r^{\mathrm{e}} ; H / c^{c h}$ animals, respectively. $A^{y} / a$; $\mathrm{c}^{\mathrm{ch}} / \mathrm{c}^{\mathrm{ch}}$ animals were easily identified by their cream-colored phenotype. Presumptive Mclre/Mclre; $\mathrm{c}^{\mathrm{ch}} / \mathrm{c}^{\mathrm{ch}}$ animals were selected by a coat color phenotype of pale yellow with eumelanin ticking, and their genotype confirmed by progeny testing. The results described here were obtained on a C57BL/6J back- ground; similar results have been described for $\mathrm{A}^{\mathrm{y}}$ and $\mathrm{Mcl} \mathrm{r}^{\mathrm{e}}$ by Feldman (1935) and Searle and Beechey (1970), respectively, for a mixed genetic background. In this earlier work, and as summarized by Silvers (1979b), the coat color phenotypes of $a / a$; $H+; c^{c h} / c^{c h}$ and $A^{y} / a ; H+; c^{c h} / c^{c h}$ animals are described as sepia and ivory, respectively; here we use the designations black and cream-colored. In addition, we describe lethal yellow and recessive yellow animals as yellow; in fact, these classes exhibit subtle coat color differences and can often be distinguished. recessive yellow (a/a; $\left.\mathrm{Mclr}^{\mathrm{e}} / \mathrm{Mclr}^{\mathrm{e}} ;+++\right)$ animals are darker (sooty) than lethal yellow $\left(\mathrm{A}^{\mathrm{y}} / \mathrm{a} ; H+;++\right)$ animals, especially prior to weaning.

The phenotype displayed by $\mathrm{Mclr} / \mathrm{Mclr} \mathrm{r}^{\mathrm{e}} ; \mathrm{c}^{\mathrm{ch}} / \mathrm{c}^{\mathrm{ch}}$ animals, pale yellow with eumelanin ticking, is easily distinguished from $A^{y} / a ; c^{c h} / c^{c h}$ animals by the presence of eumelanin, and from $M c l r^{\mathrm{e}} / \mathrm{Mclr}^{\mathrm{e}} ;+/ \mathrm{c}^{\mathrm{ch}}$ animals by the intensity of the yellow color.

To establish a cross in which both $A^{y}$ and $M c l r^{e}$ were segregating, cream-colored $A^{y} / a ; H+; c^{c h} / c^{c h}$ animals were bred to pale yellow a/a; Mclre/Mclre; $c^{c h} / c^{c h}$ animals, a cross of $\left(A^{y} / a\right.$; $\left.+/ M c l r^{\mathrm{e}} ; c^{c h} / c^{c h} \times a / a ;+/ M c 1 r^{\mathrm{e}} ; c^{c h} / c^{c h}\right)$ was set up from the $F_{1}$ progeny, and breeding pairs of $F_{2}$ animals were identified that produced both pal eyel low and cream-colored progeny. For these $\mathrm{F}_{2}$ kindreds, genotypes at the Agouti and Mclr loci were determined by Southern blotting and direct sequencing of PCR-amplified genomic DNA, respectively, as described previously (Miller et al. 1997).

\section{Acknowledgments}

We are grateful to Dr. Michael Lerner and members of the Lerner laboratory for providing Xenopus melanophores as well as ancillary reagents and protocols for mel anophore growth. We thank Dr. Teresa Gunn for hel p with genotyping, Dr. Karl Reich and Cindy Harryman-Samos for their hel pful advice with chromatography and binding assays, respectively, and Drs. Linda Rehfuss and Brian Kobilka for the Mc1r and SFB2 plasmids, respectively. M.M.O. and B.D.W. are supported by graduate (EY 07106) and medical scientist trainee (GM 07365) training grants, respectively. This work was supported in part by grants from the N ational Institutes of Heal th to M.L.L. (EY 10223) and to G.S.B. (DK28506) who is an Associate Investigator of the Howard Hughes Medical Institute.

The publication costs of this article were defrayed in part by payment of page charges. This article must therefore be hereby marked "advertisement" in accordance with 18 USC section 1734 solely to indicate this fact.

\section{References}

Adan, R.A.H., M. Vanderkraan, R.P. Doornbos, P.R. Bar, and J.P.H. Burbach. 1996. M el anocortin receptors mediate al pha$\mathrm{MSH}$-induced stimulation of neurite outgrowth in neuro 2A cells. Mol. Brain Res. 36: 37-44.

Barsh, G.S. 1996. The genetics of pigmentation: From fancy genes to complex traits. Trends Genet. 12: 299-305.

Blanchard, S.G., C.O. Harris, O.R.R. Ittoop, J.S. Nichols, D.J. Parks, A.T. Truesdale, and W.O. Wilkison. 1995. Agouti antagonism of melanocortin binding and action in the B16F10 murine melanoma cell line. Biochemistry 34: 10406-10411.

Bultman, S.J., E.J. Michaud, and R.P. Woychik. 1992. Molecular characterization of the mouse agouti locus. Cell 71: 11951204.

Chhajlani, V. and J.E.S. Wikberg. 1992. Molecular cloning and expression of the human melanocyte stimulating hormone receptor cDN A. FEBS Lett. 309: 417-420. 
Cone, R.D., D. Lu, S. Koppula, D.I. Vage, H. Klungland, B. Boston, W. Chen, D.N. Orth, C. Pouton, and R.A. Kesterson. 1996. The melanocortin receptors: Agonists, antagonists, and the hormonal control of pigmentation. Recent Prog. Horm. Res. 51: 287-318.

Conklin, B.R. and H.R. Bourne. 1993. M ouse coat colour reconsidered. Nature 364: 110.

Dores, R.M., L.K. M cD onald, T.C. Steveson, and C.A. Sei. 1990. The molecular evolution of neuropeptides: Prospects for the '90s. Brain Behav. Evol. 36: 80-99.

Eberle, A.N. 1988. The melanotropins. Chemistry, physiology and mechanism of action. Karger, Basel.

Fan, W., B.A. Boston, R.A. Kesterson, V.J. Hruby, and R.D. Cone. 1997. Role of melanocortinergic neurons in feeding and the agouti obesity syndrome. Nature 385: 165-168.

Feldman, H.W. 1935. A fifth allelomorph in the al bino series of the house mouse. J. Mammal. 16: 207-210.

Gantz, I., H. Miwa, Y. Konda, Y. Shimoto, T. Tashiro, S.J. Watson, J. Delvalle, and T. Yamada. 1993. Molecular cloning, expression, and gene localization of a 4th melanocortin re ceptor. J. Biol. Chem. 268: 15174-15179.

Geschwind, I.I. 1966. Change in hair color in mice induced by injection of $\alpha \mathrm{MSH}$. Endocrinology 79: 1165-1167.

Guan, X.M., T.S. Kobilka, and B.K. Kobilka. 1992. Enhancement of membrane insertion and function in a type IIIb membrane protein following introduction of a cleavable signal peptide. J. Biol. Chem. 267: 21995-21998.

Haskell-Luevano, C., T.K. Sawyer, S. Hendrata, C. North, L. Panahinia, M. Stum, D.J. Staples, A.M.D. Castrucci, M.E. Hadley, and V.J. Hruby. 1996a. Truncation studies of al phamelanotropin peptides identify tripeptide anal ogues exhibiting prolonged agonist bioactivity. Peptides 17: 995-1002.

Haskell-Luevano, C., T.K. Sawyer, S. Trumpp-Kallmeyer, J.A. Bikker, C. Humblet, I. Gantz, and V.J. Hruby. 1996b. Threedimensional molecular models of the hMC1R melanocortin receptor: Complexes with melanotropin peptide agonists. Drug Design Discov. 14: 197-211.

Huang, Q.H., M.L. Entwistle, J.D. Alvaro, R.S. Duman, V.J. Hruby, and J.B. Tatro. 1997. Antipyretic role of endogenous melanocortins mediated by central melanocortin receptors during endotoxin-induced fever. J. Neurosci. 17: 3343-3351.

Hunt, G. and A.J. Thody. 1995. Agouti protein can act independently of melanocyte-stimulating hormone to inhibit melanogenesis. J. Endocrinol. 147: R1-R4.

Huszar, D., C.A. Lynch, V. FairchildH untress, J.H. Dunmore, Q. Fang, L.R. Berkemeier, W. Gu, R.A. Kesterson, B.A. Boston, R.D. Cone et al. 1997. Targeted disruption of the melanocortin-4 receptor results in obesity in mice. Cell 88: 131-141.

Jackson, I.J. 1993. M olecular genetics. Colour-coded switches. Nature 362: 587-588.

Jayawickreme, C.K., J.M. Quillan, G.F. Graminski, and M.R. Lerner. 1994. Discovery and structure-function analysis of al pha-mel anocyte-stimulating hormone antagonists. J. Biol. Chem. 269: 29846-29854.

Jones, B.H., J.H. Kim, M.B. Zemel, R.P. Woychik, E.J. Michaud, W.O. Wilkison, and N. M oustaid. 1996. U pregulation of adipocyte metabolism by agouti protein: Possible paracrine actions in yellow mouse obesity. Am. J. Physiol.-Endocrinol. Metab. 33: E192-E196.

Kenakin, T.P. 1982. The Schild regression in the process of receptor classification. Can. J. Physiol. Pharmacol. 60: 249265.

Kiefer, L.L., O.R.R. Ittoop, K. Bunce, A.T. Truesdale, D.H. Willard, J.S. Nichols, S.G. Blanchard, K. Mountjoy, W.J. Chen, and W.O. Wilkison. 1997. Mutations in the carboxyl terminus of the agouti protein decrease agouti inhibition of ligand binding to the melanocortin receptors. Biochemistry 36: 2084-2090.

Kim, J.H., R.L. Mynatt, J.W. Moore, R.P. Woychik, N . M oustaid, and M .B. Zemel. 1996. The effects of cal cium channel blockade on agouti-induced obesity. FASEB J. 10: 1646-1652.

Kobayashi, T., W.D. Vieira, B. Potterf, C. Sakai, G. Imokawa, and V.J. Hearing. 1995. Modulation of melanogenic protein expression during the switch from eu- to pheomelanogenesis. J. Cell Sci. 108: 2301-2309.

Lefkowitz, R.J., S. Cotecchia, M.A. Kjelsberg, J. Pitcher, W.J. Koch, J. Inglese, and M.G. Caron. 1993. Adrenergic receptors: Recent insights into their mechanism of activation and desensitization. Adv. Second Messenger Phosphoprotein Res. 28: 1-9.

Li, S.J., K. Varga, P. Archer, V.J. Hruby, S.D. Sharma, R.A. Kesterson, R.D. Cone, and G. Kunos. 1996. Melanocortin antagonists define two distinct pathways of cardiovascular control by al pha- and gamma-melanocyte-stimulating hormones. J. Neurosci. 16: 5182-5188.

Lu, D.S., D. Willard, I.R. Patel, S. Kadwell, L. Overton, T. Kost, M. Luther, W.B. Chen, R.P. Woychik, W.O. Wilkison, and R.D. Cone. 1994. Agouti protein is an antagonist of the me lanocyte-stimulating-hormone receptor. Nature 371: 799802.

Manne, J., A.C. Argeson, and L.D. Siracusa. 1995. M echanisms for the pleiotropic effects of the agouti gene. Proc. Natl. Acad. Sci. 92: 4721-4724.

Michaud, E.J., S.J. Bultman, M.L. Klebig, M.J. van Vugt, L.J. Stubbs, L.B. Russell, and R.P. Woychik. 1994. A molecular model for the genetic and phenotypic characteristics of the mouse lethal yellow (Ay) mutation. Proc. Natl. Acad. Sci. 91: 2562-2566.

Millar, S.E., M.W. Miller, M.E. Stevens, and G.S. Barsh. 1995. Expression and transgenic studies of the mouse agouti gene provide insight into the mechanisms by which mammalian coat color patterns are generated. Development 121: 32233232.

Miller, K.A., T.M. Gunn, M.M. Carrasquillo, M.L. Lamoreux, D.B. Galbraith, and G.S. Barsh. 1997. Genetic studies of the mouse mutations mahogany and mahoganoid. Genetics 146: 1407-1415.

Miller, M.W., D.M.J. Duhl, H. Vrieling, S.P. Cordes, M.M. Ollmann, B.M. Winkes, and G.S. Barsh. 1993. Cloning of the mouse agouti gene predicts a secreted protein ubiquitously expressed in mice carrying the Lethal-Yellow mutation. Genes \& Dev. 7: 454-467.

M iwa, H., I. Gantz, Y. Konda, Y. Shimoto, and T. Yamada. 1995. Structural determinants of the melanocortin peptides required for activation of melanocortin-3 and melanocortin-4 receptors. J. Pharmacol. Exp. Ther. 273: 367-372.

Mountjoy, K.G., L.S. Robbins, M.T. Mortrud, and R.D. Cone. 1992. The cloning of a family of genes that encode the melanocortin receptors. Science 257: 1248-1251.

Movaghar, M. 1989. Tyrosinase activity in the first coat of agouti and black mice. Pigment Cell Res. 2: 401-407.

Mynatt, R.L., R.J. Miltenberger, M.L. Klebig, M.B. Zemel, J.E. Wilkinson, W.O. Wilkinson, and R.P. Woychik. 1997. Combined effects of insulin treatment and adipose tissue-specific agouti expression on the devel opment of obesity. Proc. Natl. Acad. Sci. 94: 919-922.

Olivera, B.M., J. Rivier, J.K. Scott, D.R. Hillyard, and L.J. Cruz. 1991. Conotoxins. J. Biol. Chem. 266: 22067-22070.

Ollmann, M.M., B.D. Wilson, Y.-K. Yang, J.A. Kerns, Y. Chen, I. Gantz, and G.S. Barsh. 1997. Antagonism of central melanocortin receptors in vitro and in vivo by Agouti-related protein. Science 278: 135-138. 
Potenza, M.N . and M.R. Lerner. 1992. A rapid quantitative bioassay for evaluating the effects of ligands upon receptors that modulate CAMP levels in a melanophore cell line. Pigment Cell Res. 5: 372-378.

Prota, G. 1992. Melanins and melanogenesis. Academic Press, San Diego, CA.

Prota, G., M.L. Lamoreux, J. Muller, T. Kobayashi, A. Napolitano, M.R. Vincensi, C. Sakai, and V.J. Hearing. 1995. Comparative analysis of melanins and melanosomes produced by various coat color mutants. Pigm. Cell Res. 8: 153-163.

Prusis, P., P.A. Frandberg, R. Muceniece, I. Kalvinsh, and J.E. Wikberg. 1995. A three dimensional model for the interaction of MSH with the melanocortin-1 receptor. Biochem. Biophys. Res. Comm. 210: 205-210.

Quistad, G.B. and W.S. Skinner. 1994. Isolation and sequencing of insecticidal peptides from the primitive hunting spider, Plectreurys tristis (Simon). J. Biol. Chem. 269: 11098-11101.

Robbins, L.S., J.H. N adeau, K.R. Johnson, M.A. Kelly, L. Rosellirehfuss, E. Baack, K.G. Mountjoy, and R.D. Cone. 1993. Pigmentation phenotypes of variant extension locus alleles result from point mutations that alter $\mathrm{MSH}$ receptor function. Cell 72: 827-834.

Sakai, C., M. Ollmann, T. Kobayashi, Z. A bdel-Malek, J. Muller, W.D. Vieira, G. Imokawa, G.S. Barsh, and V.J. Hearing. 1997. Modulation of murine melanocyte function in vitro by agouti signal protein. EMBO J. 16: 3544-3552.

Sasai, Y., B. Lu, H. Steinbeisser, and E.M. De Robertis. 1995. Regulation of neural induction by the Chd and Bmp-4 antagonistic patterning signals in Xenopus. Nature 376: 333336.

Searle, A.G. and C.V. Beechey. 1970. The phenotypic effects of $\mathrm{d}, \mathrm{In}$ and cch on $\mathrm{Ay}$, e and wild type. Mouse News Lett. 42: 28.

Shutter, J.R., M. Graham, A.C. Kinsey, S. Scully, R. Luthy, and K.L. Stark. 1997. Hypothalamic expression of ART, a novel gene related to agouti, is up-regulated in obese and diabetic mutant mice. Genes \& Dev. 11: 593-602.

Siegrist, W., D.H. Willard, W.O. Wilkison, and A.N. Eberle. 1996. Agouti protein inhibits growth of b16 melanoma cells in vitro by acting through mel anocortin receptors. Biochem. Biophys. Res. Comm. 218: 171-175.

Siegrist, W., R. Drozdz, R. Cotti, D.H. Willard, W.O. Wilkison, and A.N. Eberle. 1997. Interactions of al pha-melanotropin and agouti on B16 melanoma cells: Evidence for inverse agonism of agouti. J. Recep. Signal Transductor Res. 17: 75-98.

Silvers, W.K. 1979a. The agouti and extension series of alleles, umbrous and sable. In The coat colors of mice. pp. 6-44. Springer-Verlag, N ew York, NY.

- - 1979b. Recessive yellow and lethal yellow: Similarities and differences. In The coat colors of mice. pp. 30-31. Springer-Verlag, N ew York, NY.

Siracusa, L.D. 1994. The agouti gene: Turned on to yellow. Trends Genet. 10: 423-428.

Suzuki, I., A. Tada, M.M. Ollmann, G.S. Barsh, S. Im, M.L. Lamoreux, V.J. Hearing, J.J. N ordlund, and Z.A. AbdelMalek. 1997. Agouti signaling protein inhibits melanogenesis and the response of human melanocytes to al pha-melanotropin. J. Invest. Dermatol. 108: 838-842.

Vage, D.I., D.S. Lu, H. Klungland, S. Lien, S. Adalsteinsson, and R.D. Cone. 1997. A non-epistatic interaction of agouti and extension in the fox, Vulpes vulpes. Nature Genet. 15: 311315.

Vrieling, H., D.M. Duhl, S.E. Millar, K.A. Miller, and G.S. Barsh. 1994. Differences in dorsal and ventral pigmentation result from regional expression of the mouse agouti gene. Proc. Natl. Acad. Sci. 91: 5667-5671.
Willard, D.H., W. Bodnar, C. Harris, L. Kiefer, J.S. Nichols, S. Blanchard, C. Hoffman, M. Moyer, W. Burkhart, J. Weiel et al. 1995. A gouti structure and function: Characterization of a potent alpha-melanocyte stimulating hormone receptor antagonist. Biochemistry 34: 12341-12346.

Yang, Y.K., M.M. Ollmann, B.D. Wilson, C. Dickinson, T. Yamada, G.S. Barsh, and I. Gantz. 1997. Effects of recombinant agouti-signaling protein on melanocortin action. Mol. Endocrinol. 11: 274-280.

Zemel, M.B., J.H. Kim, R.P. Woychik, E.J. Michaud, S.H. Kadwell, I.R. Patel, and W.O. Wilkison. 1995. Agouti regulation of intracellular calcium: Role in the insulin resistance of viable yellow mice. Proc. Natl. Acad. Sci. 92: 4733-4737. 


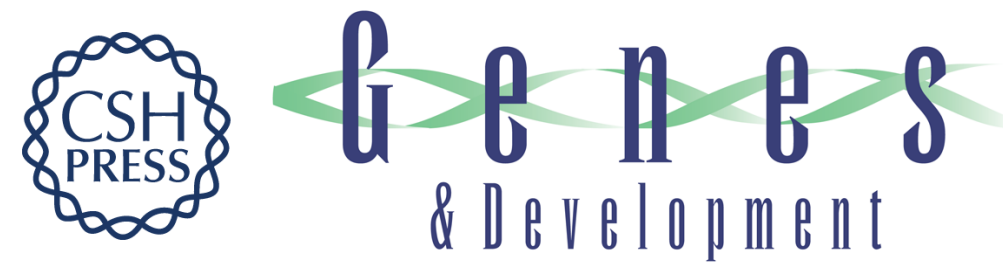

\section{Interaction of Agouti protein with the melanocortin 1 receptor in vitro and in vivo}

Michael M. Ollmann, M. Lynn Lamoreux, Brent D. Wilson, et al.

Genes Dev. 1998, 12:

\section{References This article cites 55 articles, 22 of which can be accessed free at: http://genesdev.cshlp.org/content/12/3/316.full.html\#ref-list-1 \\ License}
Email Alerting Receive free email alerts when new articles cite this article - sign up in the box at the top Service right corner of the article or click here.

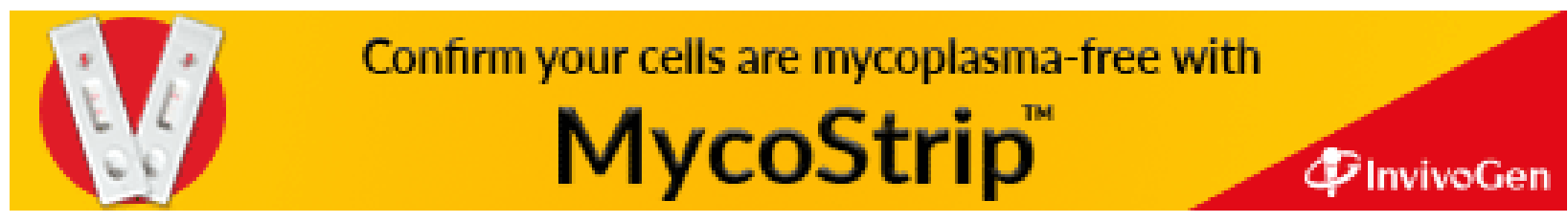

